\title{
ECONOMIC AND POLITICAL CONSIDERATIONS OF THE COURT'S CASE LAW POST CRISIS: AN EXAMPLE FROM TAX LAW AND THE INTERNAL MARKET
}

\begin{abstract}
Katerina Pantazatou*
Summary: This paper investigates whether the 'Euro crisis' has altered the Court of Justice's legal reasoning in the area of the four freedoms and direct taxation. In view of the tremendous budgetary implications of the Court's judgments in the area of direct taxation, this paper departs from the hypothesis that the financial crisis could result in the adoption of a more 'lenient' approach by the Court towards the Member States' national budgets (in particular those under financial assistance). By deploying three different indicators, the interpretation and use of the general principles of EU law, the limitation of the temporal effects of the judgment, and the number of references for preliminary rulings, this paper concludes that the Court has not been as affected by the financial crisis as initially suspected.
\end{abstract}

\section{Introduction}

The goal of this paper is to research the case law of the Court of Justice in the area of (direct) taxation and the internal market in the 'aftermath' of the economic crisis. It aims to investigate whether the so-called "Euro crisis" has somehow contributed to the evolution of the four freedoms and direct taxation case law of the Court, in particular with regard to the interpretative tools the Court uses and the meaning it attaches to the general principles of EU law.

Given that the Court's judgments in the area of direct taxation have, very often, tremendous budgetary implications for the Member States which are, hence, coerced to change their tax systems, the paper wishes to explore whether the present economic crisis has compelled the Court to take into account (more than it usually does) economic considerations, especially when the amounts at stake are very high. If we accept that the Court of Justice often engages in policy making and assumes a

\footnotetext{
PhD European University Institute. I would like to thank the participants of the Workshop organised by the Jean Monnet Chair of European Public Law, University of Zagreb, Faculty of Law: 'Internal Market in the Time of Economic Crisis - Restrictions and Justifications', and two anonymous referees for very useful comments on a preliminary version of this paper.

1 The term 'Euro crisis' is used to describe the situation that erupted in autumn 2008 with the collapse of Lehman Brothers and soon spread to the EU. It encompasses all the different terms used to elucidate the present multiple crises the EU is suffering from: financial crisis, economic crisis, sovereign debt crisis, legitimacy crisis, crisis of democracy and accountability.
} 
political role, we could reasonably hypothesise that the economic crisis would have the effect that the Court in these difficult times is trying to safeguard the Member States' budgets / public finance in order to avoid any further need for borrowing, further damage to national budgets and to ensure the recovery of the most affected countries and the repayment of their debts, by adopting a more 'lenient' approach towards the Member States and their national budgets.

\section{The CJEU's role in national budgetary policies}

It is evident that the CJEU judgments can have a significant, if not tremendous, impact on the budgets of the Member States. ${ }^{2}$ The budgetary consequences of the judgments delivered by the Court in the field of taxation have been the subject of discussion at the political level, ${ }^{3}$ which has allegedly triggered a shift in the Court's approach in the adjudication of direct taxation cases. ${ }^{4}$ Indicatively, the Bosal judgment ${ }^{5}$ cost the Netherlands $€ 1.2$ billion per year between 2003 and 2010 , and had the outcome of the Marks and Spencer ${ }^{6}$ judgment been different, several Member States would have been forced to change their tax rules, while the German government would have counted losses of approximately $€ 30$ billion. ${ }^{7}$ Similarly, in the (first) Test Claimants FII case, ${ }^{8}$ the UK requested the CJEU to limit the temporal effect of its judgment, because settling claims arising from a British tax provision enacted in 1974 would cost the government an estimated $£ 7$ billion. To exemplify the numbers, the outcome of a 'serious' case of corporate income taxation could equal or even exceed the amount needed for the 'bail out' of Ireland. ${ }^{9}$

Eventually, a decision by the CJEU on the incompatibility of a national tax measure with one of the four freedoms affects the national bud-

\footnotetext{
2 See, however, Servaas van Thiel, 'The Direct Income Tax Case Law of the European Court of Justice: Past Trends and Future Developments' (2008) 62 Tax Law Review 145, 186-188, who argues that the criticism that the CJEU's decisions are very expensive and that they might even carry the more fundamental risk of pushing the Member States to decide their own socioeconomic model, is exaggerated. Van Thiel's argument is grounded on the difficulty to exactly estimate the amounts at stake, the far-stretched argument about the implications on the social policies of the Member States and the relatively small amounts compared to the state aids cases.

3 ECOFIN Council, Press Release of the $2638^{\text {th }}$ Council Meeting, February 2005, 6141/05 and Press Release of the $2666^{\text {th }}$ Council Meeting, June 2005.

4 See under subsection 4.1 the discussion on the shift in the Court's case law in 2005, the same year as the discussions in the ECOFIN Council (n 3).

5 Case C-168/01 Bosal [2003] ECR I-9409.

6 Case C-446/03 Marks and Spencer [2005] ECR I-2283.

7 See Peter Gumbel, 'Taking the Taxman to Court' (2005) 165(16) Time Europe (18 April).

8 Case C-446/04 Test Claimants in the FII Group Litigation [2006] ECR I-11753.

9 According to the official EFSF website, the total amount lent to Ireland by the EFSF amounts to $€ 17.70$ billion <http://www.efsf.europa.eu/about/operations/index.htm> accessed 4 December 2013.
} 
gets in multiple ways: first of all, the Member State will have to remove the discriminatory provision to raise revenue, in accordance with Article 260 TFEU, which further implies that in order to balance its budget it will have either to cut spending or increase revenue through other taxes. ${ }^{10}$ The second 'budgetary trap' for the Member States is premised on the fact that the CJEU's decisions are generally retroactive, and therefore the Member States are obliged to refund with interest any discriminatory taxes they have already collected. ${ }^{11}$ Finally, the effect of the CJEU's decision is not limited to the defendant Member State. In contrast, a negative decision for the Member State might either trigger an avalanche of appeals or group litigation orders against other Member States, or the latter will pre-emptively have to adapt their laws accordingly in order to avoid proceedings before the Court.

Despite the fact that, according to settled case law, justifications based on purely economic reasons (ie the loss of fiscal revenues) are not accepted by the Court, ${ }^{12}$ and despite the possible but exceptional application of the limitation of the temporal effects of the CJEU's judgments, ${ }^{13}$ it is suspected that CJEU judges always have at the back of their mind the huge sums at stake in direct taxation cases. ${ }^{14}$

\section{The Court's contribution in the budgetary policies of the Member States}

There are several possibilities for the Member States to reduce spending and ensure fiscal discipline and compliance. Notwithstanding the traditional $^{15}$ and innovative ${ }^{16}$ economic governance measures premised

\footnotetext{
10 Ruth Mason, 'Made in America for European Tax: The Internal Consistency Test' (2008) 49 Boston College Law Review 1277, 1279.

11 Case C-294/99 Athinaiki Zithopiia [2001] ECR I-6797.

12 See for instance Cases C-264/96 ICI [1998] ECR I-4695, para 28; C-307/97 Saint-Gobain [1999] ECR I-6163, para 50.

13 See Case C-292/04 Meilicke and Others [2007] ECR I-1835 and Michael Lang, 'Limitation of the Temporal Effects of Judgments of the ECJ' in Dennis Weber (ed), The Influence of European Law on Direct Taxation (Kluwer Law International 2007).

14 Of the same opinion AG Jacobs in Case C-475/03 Banca Popolare di Cremona v Agenzia Entrate Ufficio Cremona [2006] ECR I-9373, and Michael Lang, 'The Marks and Spencer Case: The Open Issues Following the ECJ's Final Word' (2006) European Taxation 54, 67 who mainly suggests that the ECJ's decision in the Marks and Spencer case might have been motivated by revenue considerations.

15 Article 125 TFEU (ex Article 103 TEC, 'no bail out clause'), Art 126 TFEU (ex Article 104 TEC, Excessive Deficit Procedure), Stability and Growth Pact Regulations: Council Regulation (EC) 1466/97 of 7 July 1997 on the strengthening of the surveillance and co-ordination of budgetary positions [1997] OJ L209/1, and Council Regulation (EC) 1467/97 of 7 July 1997 on speeding up and clarifying the implementation of the Excessive Deficit Procedure [1997] OJ L209/6.

16 See, for example, the new economic governance mechanisms: 'Six Pack Agreement': Regulation 1175/2011 amending Regulation 1466/97 on the strengthening of the survei-
} 
on the Treaty and on secondary legislation (grounded on fiscal consolidation, fiscal discipline and economic surveillance measures) destined to safeguard balanced budgets within the EU and the EMU, this paper will contemplate the Court's role and influence with reference to the Member States' budgets in the context of financial crisis.

The Court has traditionally been perceived as an integration catalyst ${ }^{17}$ or, with a negative connotation, an 'integration activist'. ${ }^{18}$ In particular, in previous crises, like the empty chair crisis of 1965 and the oil crisis of the late 1970s, the CJEU 'stepped in and held the construct together'. ${ }^{19}$ During these crises, the integrationist impetus was bestowed by the Court via the making of constitutional principles such as the doctrines of supremacy, ${ }^{20}$ direct effect, ${ }^{21}$ state liability, ${ }^{22}$ whereas in the late 1970s the CJEU interpreted the EC Treaty, in the free movement of goods context, as prohibiting not only overt discrimination - as was explicitly stated under the non-discrimination principle (Article $12 \mathrm{EC}$ ) - but also covert discrimination that would hinder cross-border situations. ${ }^{23}$

llance of budgetary positions and the surveillance and coordination of economic policies [2011] OJ L306/12; Regulation 1177/2011 amending Regulation 1467/97 on speeding up and clarifying the implementation of the excessive deficit procedure [2011] OJ L306/33; Regulation $1173 / 2011$ on the effective enforcement of budgetary surveillance in the euro area [2011] OJ L306/1; Directive 2011/85/EU on requirements for budgetary frameworks of the Member States [2011] OJ L306/41; Regulation 1176/2011 on the prevention and correction of macroeconomic imbalances [2011] OJ L306/25; Regulation 1174/2011 on enforcement measures to correct macroeconomic imbalances in the euro area [2011] OJ L306/8; the Treaty on Stability, Coordination and Governance in the Economic and Monetary Union ('Fiscal Compact'), the European Semester, the European Stability Mechanism Treaty, as well as the amendment of Article 136 TFEU.

17 Mauro Cappelletti, 'Is the European Court Running Wild?' (1987) 12 EL Rev 3; Joseph HH Weiler, 'The Court of Justice on Trial' (1987) 24 CML Rev 555; Lord Howe of Aberavon 'Euro-Justice: Yes or No?' (1996) 21 EL Rev 187; D Edward, 'Judicial Activism: Myth or Reality?' in AI Campbell and M Voyatzi (eds) Legal Reasoning and Judicial Interpretation of European Law: Essays in Honour of Lord Mackenzie-Stuart (Trenton Publishing 1996); Anthony Arnull, 'The European Court and Judicial Objectivity: A Reply to Professor Hartley' (1996) 112 LQR 411. For a more general approach, see Lord Slynn, The Court of Justice of the European Communities' (1984) 33 ICLQ 409; Takis Tridimas, 'The Court of Justice and Judicial Activism' (1996) 21 EL Rev 199.

18 Hjalte Rasmussen, On the Law and Policy of the European Court of Justice (Martinus Nijhoff 1986); Hjalte Rasmussen, 'Between Self-restraint and Activism: A Judicial Policy for the European Court of Justice' (1988) 13 EL Rev 28; Sir P Neill, 'The European Court of Justice: A Case-study in Judicial Activism' (Memorandum presented before the House of Lords Select Committee on the European Communities, 18th Report (1994-95) Session) 218; TC Hartley, 'The European Court, Judicial Objectivity and the Constitution of the European Union' (1996) 112 LQR 95.

19 Joseph HH Weiler, 'The Transformation of Europe' (1991) 100(8) Yale Law Journal Symposium: International Law 2425.

20 See Case C- 6/64 Flaminio Costa v ENEL [1964] ECR 585.

21 C-26/62 Van Gend en Loos v Nederlandse Administratie der Belastingen [1963] ECR 1 (Van Gend en Loos).

22 Case C-6/90 Francovich and Bonifaci v Italy [1991] I-05357.

23 Case 120/78 Rewe-Zentral [1979] ECR (Cassis de Dijon); Case C-288/89 Collectieve An- 
Later, it went one step further to find 'any restriction liable to hinder' the free movement of goods incompatible with the Treaty. ${ }^{24}$

This 'pro-integration bias', by aiming at further economic integration, and thus, eventually, the completion of the internal market, can however have counter effects on the Member States' national laws and in particular their tax systems. Consequently, the Court, by finding discrimination where there was none, or by finding restriction in the simple interaction between two tax systems (or tax jurisdictions), was allowed to interfere in the tax policies of the Member States and strike down perfectly non-discriminatory tax systems. In this sense, the pro-integrationist tendencies of the Court clashed severely in an effort to balance the internal market objective and the tax sovereignty of the Member States.

In light of the present catastrophic crisis, one could reasonably hypothesise that the Court would, if not reverse the integration process, at least slow it down. In this way, it would not create a big 'hole' in the states' budgets, while it would allow them to develop their tax systems so as to raise as much revenue as possible in order to finance their budgets and to ensure the recovery of the most affected countries and the repayment of their debts.

In this paper I identify two possibilities where the Court can interfere with or be more lenient towards the tax systems of the Member States (and vice versa) in a crisis framework: a) via its legal reasoning and the interpretation of general principles of internal market law and the subsequent outcome of the judgments; and b) by allowing for a limitation of the temporal effects of the judgment. The last part of this paper deals with a third possibility, namely the potential reduction of references for preliminary rulings sent by the Member States to the CJEU - in an effort to protect their budgets. Although in this final case it does not rest upon the Court to decide whether or not there will be a reduction in preliminary references, it is believed that a sharp fall in preliminary references sent by the Member States to the Court could coerce it to adopt a more 'lenient' approach towards their national tax systems. Accordingly, even though the Court cannot have any influence on this factor, ie the number of references sent, the balanced collaboration between the national and the Community judge could be disrupted and the Court's reasoning could be affected by a coordinated reduction in Member States' references.

tennevoorziening Gouda [1991] ECR I-4007.

24 Case 8/74 Dassonville [1974] ECR 837; Case C-55/94 Gebhard [1995] ECR I-4165. 


\section{Financial crisis and the Court's legal reasoning in direct taxation cases}

\subsection{Pre-crisis years}

The first way the Court could take into consideration the repercussions of the financial crisis on national budgets would be by appropriately employing its legal reasoning to interpret the four freedoms provisions in a way that would not lead to striking down national tax measures. Such a scenario would mean a return to the early 'non-discrimination' test, which would 'catch' only the most 'severe' violations with the result of less integration and more leeway given to Member States to set up their own policies. By contrast, a broad interpretation of the 'market access test' and a 'narrow' justifications scope would mean removing even the most insignificant obstacles in the internal market and would inevitably eliminate the Member States' power and rights to determine their own national tax systems, ie their tax bases, tax rates and whether they want to provide relief from double taxation. ${ }^{25}$

The CJEU picked up late on direct taxation. It decided its first case on the compatibility of a French tax measure with the freedom of establishment in $1986,{ }^{26}$ and in the first years it considered direct taxation cases under a 'strict ${ }^{27}$ or a 'concealed' non-discrimination test. ${ }^{28}$ Between 1994 and 2005, the Court spent a 'judicially active' period in direct taxation, where it applied unfettered internal market principles, ${ }^{29}$ only to return to 'self-restraint' in 2005 with the D judgment. ${ }^{30}$ Until that year, around 90 to $95 \%$ of claims against direct tax rules had been successful. Quite unsurprisingly, quantitative analyses show that there has been an important increase in the number of direct tax cases brought before the CJEU from 2005 onwards, both in terms of absolute numbers and in terms of relative share in the total number of preliminary ruling procedures before the Court, the latter of which has remained relatively constant. ${ }^{31}$

\footnotetext{
25 Suzanne Kingston, The Boundaries of Sovereignty: The ECJ's Controversial Role Applying Internal Market Law to Direct Tax Measures' (2006) 9 Cambridge Yearbook of European Legal Studies 299: 'even the inalienable right of Member States to define their own tax rates could be caught by a very broad restrictions based approach: a high tax jurisdiction could make less attractive the outgoing of a secondary establishment from a low tax jurisdiction.'

26 Case C-270/83 Commission v France ('Avoir Fiscal') [1986] ECR 273.

27 Commission v France (n 26); Case C- 175/88 Klaus Biehl $v$ Administration des contributions du GrandDuché de Luxembourg [1990] ECR I-1779.

28 See, for instance, Klaus Biehl v Administration des contributions du GrandDuché de Luxembourg (n 27); Case C-204/90 Bachmann [1992] ECR I-249.

29 Peter Wattel, 'Judicial Restraint and Three Trends in the ECJ's Direct Tax Case Law' (2008) 62 Tax Law Review 205; Suzanne Kingston, 'A Light in the Darkness: Recent Developments in the ECJ's Tax Jurisprudence’ (2007) 44 CML Rev, 1321, 1338; Kingston (n 25) 287, 299.

30 Case C-376/03 D [2005] ECR I-5821.

31 Mathieu Isenbaert, EC Law and the Sovereignty of the Member States in Direct Taxation (IBFD 2010) 768.
} 
By 2005, the Court had been criticised by many tax lawyers on grounds that it had failed to grasp the legal and fiscal context of the cases before it, as well as to respect long-established international tax law principles. ${ }^{32}$ At the same time, the Court had suffered from the 'implicit' criticism of the UK, during its presidency, in the second half of 2005, which was, allegedly, dissatisfied with the growing number of non-discriminatory tax measures which were found incompatible with the four freedoms. ${ }^{33}$ Both at a political and a legal level, the Court was accused of failing to take into account the international tax principles to the benefit of EU law principles and was engaging in policy-making. This criticism arguably contributed to the Court's change of approach that emerged in 2005. From that point onwards, the Court started employing a more sophisticated analysis of the 'non-discrimination' test ${ }^{34}$ that attempted to better balance national tax sovereignty with the internal market freedoms, or, put differently, revenue (Member States) against the taxpayer, in particular in comparison to the 'middle' years. The period starting in 2005 has been characterised as 'enlightenment' in the Court's case law, ${ }^{35}$ and overall the Court was applauded for taking a more 'prudent' approach in direct taxation cases. From that point onwards, Member States started 'winning' some cases, by reason of the Court's more cautious application of the 'refined non-discrimination test' or 'refined market access test'.

The new 'refined' approach which tried to give more leeway for the Member States to allocate their taxing rights as they wished was based on a 'restrictions' based analysis, but with a twist. The comparability of situations element - inherent to the equality principle - was introduced. As such, the 'new' but not always applied test deviated from the traditional two step analysis of a strict 'market access test'36 and it instead combined the following questions: 1) are the two situations comparable? 2) is there a difference in treatment? 3) can this difference in treatment be justified on public interest grounds? 4) is the proportionality step satisfied?

\footnotetext{
32 See Peter Wattel, 'Red Herrings in Direct Tax Cases before the ECJ' (2004) 31 Legal Issues of Economic Integration; Philip Baker, 'Why It Is Time for a European Tax Tribunal'(2005) 16 Int'l Tax Rev; Luc Hinnekens, 'Territoriality-Based Taxation in an Increasingly Common Market and Globalizing Economy: Nightmare and Challenge of International Taxation in this New Age' (1993) EC Tax Review 156-157.

33 See C Giles, 'Britain in Drive to Curb Power of the ECJ' Financial Times (London, 20 June 2005); and V Houlder, 'UK Mulls Tax Changes to Shield Revenues from EU' Financial Times (London, 5 December 2004).

34 See Case C-374/04 Test Claimants in Class IV of the ACT Group Litigation [2006] ECR I-11673; Marks and Spencer (n 6); Test Claimants in the FII Group Litigation (n 8); Case C-524/04 Test Claimants in the Thin Cap Group Litigation [2007] ECR I-2107.

35 S Kingston, 'A Light in the Darkness: Recent Developments in the ECJ's Tax Jurisprudence' (2007) 44 CML Rev 1338.

36 The strict market access test is premised on two prongs: 1) is there a restriction? 2) is this restriction justified on public interest grounds?
} 
The new approach thus did not confine itself to finding an 'obstacle' in the simple interaction of two tax systems, but it demanded that the two situations be comparable and that they differentiate between domestic and cross-border situations. The 'refined approach' relies heavily on the late AG Geelhoed's opinion in the Test Claimants case ${ }^{37}$ AG Geelhoed's opinion was of great importance as it encouraged the Court to retreat from the stiff restrictions based approach by making a very crucial distinction: he basically distinguished between 'quasi restrictions' and 'true restrictions'. The former, according to the AG, arose because of the inherent differences among the national tax systems which resulted in posing additional administrative compliance burdens for 'foreign' companies, or in creating disparities between different national legal orders and division of tax jurisdictions. The quasi restrictions that emanated from the aforementioned differentiations should not, in AG Geelhoed's opinion, fall within the ambit of free movement provisions. In contrast, 'true' restrictions, that is, restrictions to free movements going beyond those resulting inevitably from the existence of different national tax systems, should fall under the prohibitions in the free movement provisions, unless they are justified. In the terminology used above, in order to be 'caught' by EU law, disadvantageous tax treatment should follow from discrimination resulting from the rules of one jurisdiction, not the disparity or division of tax jurisdiction between (two or more) Member States' tax systems. ${ }^{38}$

The distinction between quasi and true restrictions proposed by AG Geelhoed corresponds to the designation between an 'overall'39 and a 'per country' approach, ${ }^{40}$ a judicial choice which can have tremendous implications for the Member States' delimitation of taxing powers. The former

\footnotetext{
37 Test Claimants in Class IV of the ACT Group Litigation (n 34). The case concerned a UK tax measure which allowed for a tax credit for the amount of ACT (Advance Corporation Tax) paid by the subsidiary when dividends were distributed from and in the UK. However, this tax credit was not available when parent companies were not resident in the UK, based on the fact that the non resident parent was not subject to corporate taxation in the UK, although it was subject to the UK's source tax jurisdiction (fiscal territoriality). The Court followed AG Geelhoed's opinion and ruled that because the domestic versus the 'foreign' parents were not in a comparable situation, Article 43 EC was not infringed. The Court followed a 'discrimination' analysis, without mentioning anywhere the notion of restriction

38 This idea was reiterated in AG Geelhoed's Opinion in Case C-170/05 Denkavit Internationaal and Denkavit France [2006] ECR I-11949, para 20.

39 Under the overall approach, the national measure at issue is not defined solely on the basis of the domestic legal order but by the Internal Market legal order, after having taken into account the legal system of the 'competing Member States' (two levels, two competing Member States, overall approach).

40 Under the per country approach, the discriminatory or restrictive character of a national measure is assessed exclusively with reference to the domestic tax jurisdiction (one level, per country approach). If a home Member State decides to exercise its tax jurisdiction with regard to worldwide income, it should not discriminate between domestic sourced and foreign sourced income.
} 
requires that tax treatment in all the Member States involved should be taken into account when assessing whether a restriction exists. That is, even if the arising obstacle is not a result of any different treatment by one state, but rather a result of the simple interaction of two different tax systems, it should be caught under the four freedoms provisions. The 'overall approach' is 'friendlier' to the internal market and the taxpayer. ${ }^{41}$ So far in cases of conflicting tax jurisdictions, the Court has mostly deployed the overall approach, which has been characterised as the "pendulum of ruthless free movement precedence over jurisdictional consistent taxation'. ${ }^{42}$ In contrast, under the 'per country' approach, the existence of discrimination or restriction is assessed by reference to the laws of one Member State and, as such, restrictions that arise from the mere disparities between the Member States should not fall under the ambit of the freedoms provisions. This way, the "per country approach'43 indirectly promotes the preservation of the fiscal sovereignty of the Member States.

Although the tax case law of the CJEU has often followed the overall approach when analysing measures of the home state and the per country approach with respect to the measures of the host state, it remains undecided as to a definite choice between the two. With this line of argument, it remains unexplained why the Court treats differently cases of juridical and economic double taxation and why it considers the former under the (friendlier to the Member State) 'per country' approach and the latter under the (friendlier to the internal market) 'overall' one, with implications for the Member States' allocation of taxing powers. ${ }^{44}$ It remains puzzling why the Court seems willing to allocate taxing competences between Member States and provide for relief from economic double taxa-

\footnotetext{
41 Some of the cases where the Court opted for the 'overall approach' are the following: Case C-403/03 Schempp v Finanzamt München V [2005] ECR I-6421 (upholding German legislation that made deductibility of maintenance payments to a former spouse conditional on the payments being taxed in the spouse's country of residence); Case C-376/03 $D \mathrm{v}$ Inspecteur van de Belastingdienst [2005] ECR I-5821 (upholding wealth tax differences due to differences in tax treaties); Case C-336/96 Gilly v Directeur des services fiscaux du BasRhin [1998] ECR I-2793 (holding that a country of residence's limiting of foreign tax credit to the domestic tax rate did not violate the EC Treaty in the context of labour income); Case C-279/93 Schumacker [1995] ECR I-225; C-470/04 N [2006] ECR I-7409; Meilicke and Others (n 13); Marks \& Spencer (n 6); Case C-319/02 Manninen [2004] ECR I-7477.

42 Wattel (n 29) 205.

43 Case E-1/04 Fokus Bank ASA v The Norwegian State [2004]; Case C-35/98 Verkooijen [2000] ECR I-4071; Cases C-397/98 and C-410/98 Metallgesellschaft and Others [2001] ECR I-1727; Manninen (n 41).

44 See, for instance, Case C-128/08 Damseaux [2009] ECR I-6823, where the CJEU ruled that, in so far as EU law does not lay down any general criteria for the attribution of areas of competence between the Member States in relation to the elimination of double taxation within the Community, Member States are not obliged to prevent the resulting juridical double taxation. It did not, however, explain why quite often the Court attempts an allocation of taxing rights by requiring the Member States to eliminate economic double taxation.
} 
tion, whereas it renounces its competence with regard to juridical double taxation, as if the former was much more detrimental than the latter. ${ }^{45}$

\section{2. 'Crisis' case law}

The crisis broke out in $2008 .{ }^{46}$ Since then, the Court has decided at least 60 cases on direct taxation, most of them under the procedure of references for preliminary rulings (Art $267 \mathrm{TFEU}$ ). This section seeks to study whether the CJEU has followed the previously developed model of a more lenient, 'refined' approach in its later judgments, or a 'broad justifications' approach that would allow the Member States to maintain their tax systems and save their budgets. In other words, this part will attempt to examine whether a shift in the Court's reasoning and interpretation of general principles can be observed since 2008, in the area of direct taxation, similar to the one monitored in 2005. The inconsistent case law so far, the malleable nature of certain principles, in particular in the area of taxation, as well as the serious repercussions on the Member States' budgets, would suggest that the Court would resort to 'friendlier' judgments for the Member States as a result of the crisis.

What, however, can first be observed with certainty about both the 'pre-' and 'post' crisis case law of the Court on direct taxation is that no patterns can be drawn. Along the lines of the pre-crisis case law, in the post-crisis era the Court remains undecided as to which test to apply and as a result it often totters between a non-discrimination, market access test, and a 'refined test', between an 'overall' and a 'per country' approach and different tests for the establishment of comparability. In addition, it has not yet adequately clarified intolerably vague concepts, like the justifications of fiscal coherence, the balanced allocation of taxing powers and the difference between the two, an omission that allows the Court to make instrumental use of justifications so as to direct accordingly the outcomes of the judgments. While the lines between these concepts remain blurred, what can be argued with certainty is that the Court has not returned to the 'dark ages' of the unfettered market access test, when almost all national tax measures were found incompatible with EU law. Instead, the increased tendency of the Court to find the national measures at issue compatible with EU law can be observed, via either the 'refined approach' or a broad understanding and/or instrumental use of justifications or a very relaxed proportionality test. Consequently, by persistently

\footnotetext{
45 Joachim Englisch, 'Taxation of Cross Border Dividends and EC Fundamental Freedoms' (2010) 38 Intertax 197, 203; Daniel Smit, 'The Haribo and Oesterresichische Salinen Cases: To What Extent is the ECJ Willing to Remove International Double Taxation Caused by Member States?' (2011) 51 European Taxation.

46 For the purposes of this paper, the outbreak of the crisis (financial, fiscal, sovereign debt) is placed in the autumn of 2008 after the collapse of Lehmann Brothers.
} 
deploying a comparability test even in its 'restrictions' analysis, it seems that the Court founds its analysis on the 'state-friendlier' non-discrimination test between cross-border and purely national activities that are carried out within the boundaries of one and the same Member State. ${ }^{47}$

The recent case law of the CJEU on direct taxation has mostly dealt with issues on dividends' taxation and double taxation, ${ }^{48}$ group relief ${ }^{49}$ and exit taxation. ${ }^{50}$ The divergence of the existing trends will be demonstrated via a brief comparative analysis of the treatment of losses from a tax perspective by the CJEU, as well as dividends taxation and double taxation. This comparative analysis - built around two direct taxation case studies - aims to identify whether the Court has deployed the 'friendlier' to the Member States non-discrimination test, or at least elements of this test, such as the need to compare two situations before establishing a 'discriminatory restriction', whether the scope of justifications has been broadened and whether the proportionality test standards have been lowered. The section will conclude with an assessment of the findings and an evaluation of the Court's most recent reasoning by reference to the national tax laws and national budgets.

\subsubsection{Group relief cases}

The relief of groups of companies in cases of cross-border taxation remains a major, still unresolved, problem before the CJEU. Normally, the various forms of group taxation aim at attaining tax neutrality ${ }^{51}$ between holdings with various subsidiaries or branches in other Member States. Such neutrality in modern tax systems is usually achieved through group taxation systems, amongst which the most popular are group relief and group consolidation. ${ }^{52}$

\footnotetext{
47 Englisch (n 45) 203.

48 Case C-194/06 Orange European Smallcap Fund [2008] ECR I-0000; Case C-303/07 Aberdeen Property Fininvest Alpha [2009] ECR I-0000; Joined Cases C-436/08 and C-437/08 Haribo Lakritzen Hans Riegel and Österreichische Salinen [2011] ECR I-305; Case C-310/09 Accor [2011] ECR I-0000; Case C-35/11 Test Claimants in the FII Group Litigation [2012] ECR I-0000; Case C-168/11 Beker [2013] (nyr).

49 Case C-293/06 Deutsche Shell [2008] ECR I-1129; Case C-414/06 Lidl Belgium [2008] ECR I-0000; Case C-157/07 Krankenheim Ruhesitz am Wannsee-Seniorenheimstatt [2008] ECR I-8061; Case C-418/07 Papillon [2008] ECR I-8947; Case C-337/08 X Holding [2010] ECR I-0000; Case C-18/11 HMRC v Philips Electronics [2012] ECR I-0000; Case C-123/11 A Oy [2013] (nyr).

50 Case C-371/10 National Grid Indus [2011] ECR I-0000.

51 Tax neutrality means that the tax system does not cause any distortion when economic operators make a decision, for example where to establish or where to invest. See also Cesar Garcia Novoa, 'Tax Neutrality in the Exercise of The Right of Establishment within the EU and the Funding of Companies' (2010) 38 Intertax 568.

52 Adam Zalasinski, 'The Limits of the EC Concept of "Direct Tax Restriction on Free Movement Rights", the Principles of Equality and Ability to Pay, and the Interstate Fiscal Equity' (2009) 37 Intertax 282, 291.
} 
The most usual problem arising with respect to group relief is that Member States provide for the advantage of group consolidation and group relief, ie the right of a group of companies to be treated as one company and thus shift their taxable base (profits and losses) in the most beneficial way (within the group). In most cases brought before the CJEU, this relief has been granted only to domestic groups, ie groups operating within the same Member State.

In the post-2008 era, the Court has dealt several times with grouprelief cases, often following inconsistent legal reasoning. The first case to be decided within the period at issue was the Krankenheim case. ${ }^{53}$ The German measure here provided that resident companies could deduct losses incurred in a foreign permanent establishment (hereinafter: $\mathrm{PE})$, the profits of which were exempted in Germany by virtue of a DTC, on condition that when the PE turned profitable in subsequent years, the losses deducted would be recaptured up to the amount of the profits made by the PE. Austrian law, on the other hand, stipulated that the losses incurred by the PEs of foreign companies were deductible only if the company did not generate worldwide profits, the losses in question were determined on the basis of regular accounting and had not been taken into account for tax purposes during the previous tax years. Because of the two different national tax systems, Krankenheim could not deduct its final losses either in Germany or in Austria.

While the Court did not explicitly make a comparison between the two situations, it ruled that a company with a registered office in Germany and a PE in Austria is in a less favourable position (hence comparable) than it would have been if the PE were established in Germany. It thus, concluded that by reason of that difference in tax treatment, a German company could be discouraged from carrying on its business through a permanent establishment situated in Austria. ${ }^{54}$ The Krankenheim reasoning is demonstrative of the Court's tendency to find 'discriminatory restrictions', and thus of its new 'refined approach' that combines non discrimination meta tests, such as the comparability element, with 'obstacle reasoning' as shown in the public interest justifications examined.

The CJEU found the restriction justified under the resurrected fiscal coherence principle. The principle of fiscal cohesion mainly articulates that when a tax advantage is granted by a Member State to the taxpayer, the Member State is justified in 'outweighing' it by imposing a fiscal 'disadvantage' (most of the time a tax levy). Similarly, in the opposite case, when there is no tax levy by the state (fiscal disadvantage for the tax payer) the latter is not obliged to grant a fiscal advantage either

\footnotetext{
53 Krankenheim Ruhesitz am Wannsee-Seniorenheimstatt (n 49).

54 ibid paras 37-38.
} 
(usually a tax allowance). ${ }^{55}$ The measure was finally found proportionate since the losses were reintegrated only up to the amount of the profits made. As such, the Court held that it was the responsibility of the source state (the state of the PE) to allow for the loss to be utilised. ${ }^{56}$ Such an approach, together with the 'revival' of the fiscal coherence principle, seems to advocate a more 'per country' approach: the CJEU did not demand that the residence state (the state of the parent company) design its national tax system so as to take into account the possible negative results arising from the particularities of legislation of another Member State. Accordingly, the 'residence state' was not demanded by the CJEU to allow the deduction of the foreign loss, although the other contracting state did not make that possible either. ${ }^{57}$ The problem, according to the Court, lay entirely with the source state and as such it should be for it to provide for loss relief.

The second important case of the period under examination is the Papillon case. ${ }^{58}$ The French law at issue allowed for the possibility of group consolidation only if the intermediate subsidiary was French (or subject to corporation tax in France). By contrast, if the intermediate subsidiary was resident in another Member State, French law would not provide for the possibility of group consolidation. With regard to whether the measure was discriminatory, ${ }^{59}$ the Court primarily examined whether it could establish comparability between a French parent company holding a subsidiary in France and a French parent company holding a subsidiary in another Member State. The Court held that 'having regard to the objectives of the CGI (national measure) at issue in the main proceedings, those situations are thus objectively comparable'. ${ }^{60}$ Following the discrimination language, the CJEU soon shifts its analysis to a 'restrictions-based' one, reminiscent of the 'double' or 'refined market-access test'. It thus contends that:

\footnotetext{
55 The principle had only been accepted by the Court twice in 1992 and under identical facts - in Case Bachmann (n 28) and in Case C-300/90 Commission v Belgium [1992] ECR I-305. Following the Bachmann (n 28), Manninen (n 41) and Case C-471/04 Keller Holding [2006] ECR I-2107 cases, the Court had "toughened" the acceptance of the coherence justification by requiring a "direct link" between "the tax advantage concerned and the offsetting of that advantage by a particular tax levy, the direct nature of that link falling to be examined in the light of the objective pursued by the rules in question". The Court found that this direct link existed in the Krankenheim case (n 49) since the German recapture rule reflected a logical symmetry and was the complement of the deduction previously granted.

56 Krankenheim (n 49) para 50ff.

57 ibid para 49.

58 Papillon (n 49).

59 ibid para 27: 'In order to establish whether discrimination exists, the comparability of a Community situation with one which is purely domestic must be examined by taking into account the objective pursued by the national provisions at issue'.

60 ibid para 30.
} 
inasmuch as, from a taxation perspective, they put Community situations at a disadvantage compared with purely domestic situations, the provisions of the CGI at issue in the main proceedings thus constitute a restriction which is, in principle, prohibited by the provisions of the Treaty relating to the freedom of establishment.

This kind of analysis allows the Court to resort to a wide range of justifications, after, however, it has established the discrimination 'minimum standard' of comparability. With regard to the justification, the Court rejected in first place the preservation of a balanced allocation of taxing powers as a valid argument on the self-evident fact that all the companies that sought to be included in the consolidation regime were resident in the same Member State. ${ }^{61}$ It contrasted this case to the Oy $A A^{62}$ and the Marks \& Spencer ${ }^{63}$ cases where indeed the losses were recorded in a Member State other than that in which the taxpayer was resident and hence the interaction of different tax jurisdictions involved the risk of tax avoidance. The Court, nevertheless, found the national legislation justifiable on grounds of the need to preserve the coherence of the tax system, proving its willingness to re-examine its stance towards this until recently neglected justification. The Court identified the direct link needed in the fact that the neutralisation of intra-group transactions avoided, inter alia, the possibility of losses being used twice at the level of the resident companies under the tax integration regime. The CJEU found that the French consolidation system, nevertheless, went beyond what was necessary to ensure the coherence of the tax system and thus failed the proportionality test, on the grounds that pursuant to the Mutual Assistance Directive ${ }^{64}$ the Member States were allowed and encouraged to exchange information that would enhance transparency in cross-border transfers.

The $X$-Holding case ${ }^{65}$ attempted to answer the question of whether a Dutch measure giving the possibility of consolidation only when all the 'parts' of the group of companies fell under the Dutch fiscal jurisdiction was compatible with EU law. Along the lines established in the earlier judgments, the Court commenced its analysis by examining whether the situation between a resident parent wishing to form a single tax entity with a resident subsidiary was comparable to the situation of a resident

\footnotetext{
61 ibid paras 37-40.

62 Case C-231/05 Oy AA [2007] ECR I-6373.

63 Marks \& Spencer (n 6).

64 Council Directive (EU) 2011/16 of 15 February 2011 on the administrative cooperation in the field of taxation and repealing Council Directive (EEC) 77/799 of 19 December 1977 on the mutual assistance by the competent authorities of Member States in the field of direct taxation and taxation of insurance premiums.

65 Case C-337/08 X Holding [2010] ECR I-1215.
} 
parent wishing to form a single tax entity with a non resident subsidiary. The CJEU ruled that the two situations were objectively comparable with regard to "the objective of a tax scheme such as that at issue in the main proceedings in so far as each seeks to benefit from the advantages of that scheme', ${ }^{66}$ which, in particular, 'allows the profits and losses of the companies constituting the single tax entity to be consolidated at the level of the parent company and the transactions carried out within the group to remain neutral for tax purposes. ${ }^{967}$ Once it had established comparability, and hence a difference in treatment, the Court proceeded to examine whether this discriminatory treatment could be justified by overriding reasons in the general interest. ${ }^{68}$

At this level, the Court found that the Dutch measure was justified on the grounds of the need to safeguard the balanced allocation of taxing powers. The $X$-Holding case provides the first case where the 'balanced allocation of taxing powers justifications' ${ }^{\prime}$ 'standing alone' was successful. ${ }^{70}$ The Court justified its answer by stating that since the parent company was at liberty to decide to form a tax entity with its subsidiary and, with equal liberty, to dissolve such an entity from one year to the next, 'the possibility of including a non-resident subsidiary in the single tax entity would be tantamount to granting the parent company the freedom to choose the tax scheme applicable to the losses of that subsidiary and the place where those losses are taken into account. ${ }^{71}$ After passing the 'justifications' test, the Dutch rule successfully met the proportionality criteria. Quite surprisingly and similar to the earlier Lidl Belgium case, ${ }^{72}$ the CJEU rejected the argument advanced by the European Commission and the plaintiff about the existence of a less restrictive measure based on a deduction recaptu-

\footnotetext{
66 The far-reaching implications of the objective used to establish comparability used therein did not escape criticism. Indeed, as Weber has pointed out, if a situation is comparable as long as you try to benefit from the domestic advantages that means that you are always in a comparable situation. See D Weber, Refusal of Advantage of a Cross-Border Tax Consolidation a Justified Restriction of the Freedom of Establishment (Comments by D. Weber on the X Holding case), (2010) 7 Highlights \& Insights on European Taxation 6.

$67 \quad X$ Holding (n 65) para 24.

68 ibid para 25.

69 The balanced allocation of taxing powers has been interpreted by the Court as an objective designed, inter alia, to safeguard the symmetry between the right to tax profits and the right to deduct losses. Lidl Belgium (n 49) para 33.

70 The justification of the 'balanced allocation of taxing powers' was first successfully put forward in Marks and Spencer (n 6), where the UK restrictive measure of the non-extension of group relief to non UK companies was justified on grounds of the balanced allocation of taxing powers, the danger of losses being used twice and the prevention of tax avoidance taken together.

71 X Holding (no 65) para 31.

72 Lidl Belgium (n 49).
} 
re rule ${ }^{73}$ and it instead considered the Dutch fiscal unity regime to be proportionate to its objective. ${ }^{74}$ The Court refused to accept that a recapture mechanism would be a less burdensome and still practicably manageable alternative to the general exclusion of foreign losses on grounds that a foreign $\mathrm{PE}$ and a foreign subsidiary were not comparable with regard to the allocation of taxing powers ${ }^{75}$ and thus, with a lack of comparable situations, "the Member State of origin remains at liberty to determine the conditions and level of taxation for different types of establishments chosen by national companies operating abroad'. ${ }^{76}$

The Philips Electronics case ${ }^{77}$ concerned a UK measure which provided that consortium claims were restricted to UK resident companies. 'Foreign' PEs were further allowed to surrender their losses only under the condition that it was clear that at the time of the claim there could never be any deduction or allowance in any other state outside the UK. Similar to the previous cases, the Court primarily sought to establish whether a non-resident company with only one PE in the UK was in a comparable situation to a resident company in the UK with regard to the possibility of transferring by means of group relief losses sustained in the UK to another company within the same group. It thus ruled that having regard to the objective of a tax regime such as that at issue in the main proceedings, the two situations were objectively comparable in so far as concerns the possibility of transferring by means of group relief losses sustained in the United Kingdom to another company in that group. ${ }^{78}$ The comparability of the two situations allowed the Court to find the UK measure restrictive to the freedom of establishment. The measure was, however, not justified on any of the grounds provided by the British government. The balanced allocation of taxing powers, the danger of the losses being used twice, as well as the combination of the two justifications, were rejected by the Court on grounds that in a situation like the one in the main proceedings

the possibility of transferring, by means of group relief and to a resident company, losses sustained by the permanent establishment in that Member State of a non-resident company is subject to a condition that those losses cannot be used for the purposes of foreign taxation, while the transfer of losses sustained in that Member State by a resident company is not subject to any equivalent condition. ${ }^{79}$

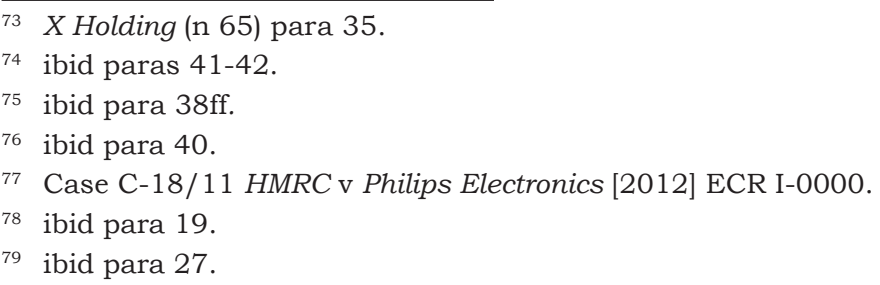


The final relevant case within the designated time framework was the $A$ Oy case. ${ }^{80}$ In principle, the Court examined whether a Finnish measure that allowed resident parent companies to take into account a resident subsidiary's losses when the latter merged with another resident subsidiary, but not if it merged with a non-resident subsidiary, was compatible with the freedom of establishment and free movement of capital. Unlike the previous cases, however, the Court did not seek to establish comparability first. In contrast, it resorted to a strict obstacles' approach, similar to the one it adhered to during its 'active years' and ruled that the Finnish measure was 'liable to make establishment in the latter state less attractive and hence to deter the company from setting up subsidiaries there'. ${ }^{81}$ Following the establishment of a restriction, the Court proceeded to moderate the 'stiff restrictions' based approach it had adopted and moved the comparability test as a potential justification for this difference in treatment. ${ }^{82}$ Pursuant to the relatively recent conceptually flawed trend to use the comparability requirement as a quasi justification, ${ }^{83}$ the Court ruled through rather tautological reasoning that the two situations were objectively comparable, on the basis of the aim of the measure, which was intended to 'allow the parent company to benefit from the tax advantage consisting in being able to deduct from tax the losses incurred by the subsidiary'. ${ }^{84}$ It, however, left it to the national Court to assess whether the deduction from taxable income of the merged company's losses would also have been refused, in the same circumstances, if the merger had been with a resident subsidiary, on the ground that the sole motive for the operation was to obtain a tax advantage. ${ }^{85}$ If that were the case, then no difference in treatment between resident and non-resident companies could be established. The Court continued by examining, along the Mar$k s$ and Spencer ${ }^{86}$ lines, whether the balanced allocation of taxing rights, the risk of tax avoidance and the danger of losses being used twice could justify this 'difference in treatment'. Following the same reasoning it had applied in the earlier Marks and Spencer case, ${ }^{87}$ the Court ruled that the Finnish measure at issue was justifiable on these three grounds ta-

\footnotetext{
80 A Oy (n 49)

81 ibid para 32.

82 ibid para 33: 'For such a difference in treatment to be compatible with the provisions of the FEU Treaty on Freedom of Establishment, it must relate to situations which are not objectively comparable or be justified by an overriding reason in the public interest.'

83 See for example Test Claimants in Class IV of the ACT Group Litigation (n 34) and Test Claimants in the FII Group Litigation (n 8); Haribo Lakritzen Hans Riegel and Österreichische Salinen (n 48).

84 A Oy (n 49) para 35.

85 ibid para 36.

${ }^{86}$ Marks and Spencer (n 6).

87 ibid.
} 
ken together. ${ }^{88}$ Finally, with regard to the proportionality of the measure, the Court, once again, followed the Marks and Spencer pattern. It hence asked the national court to decide whether the non-resident subsidiary had exhausted the possibilities available in its state of residence of having the losses taken into account there.

It can be argued, from the analysis of the case law so far, that the Court seems to persist in the view that 'forum shopping' with regard to group losses is against the balanced allocation of taxing powers or as in the Krankenheim and Papillon cases - the fiscal coherence of the Member States. The cases considered so far under the group relief 'block of cases' amplify the incoherent legal reasoning of the Court and its inability to provide guidelines that would allow for more legal certainty in this area for all the players involved. As a starting point, we can observe that the revival of the coherence principle on the one hand increased the number of potential successful justifications put forward by the Member States, but on the other hand it complicated even more the already obscure distinctions between the commonly accepted justifications (balanced allocation of taxing powers, danger of losses being used twice and the danger of tax avoidance). In sharp contrast to the Lidl Belgium judgment, which was similar on the facts, where the Court justified the restriction at issue on the need to maintain a balanced allocation of taxing powers, in the Krankenheim judgment it chose to justify the German recapture rule under the fiscal coherence principle, ${ }^{89}$ without providing clear 'reasons' for such a rather 'unjustified' choice. In addition, it has been argued that in the light of the two aforementioned judgments, the justifications seem to become exchangeable: the two justifications used in the Lidl Belgium judgment, taken 'together' as the Marks and Spencer judgment required, can be replaced by the 'magical concept' of fiscal cohesion. ${ }^{90}$

\subsubsection{Dividends taxation cases}

One of the main problems of direct taxation is the possibility of the simultaneous exercise of taxing rights by two different states. This obstacle in the free movement of both natural and legal persons can be

\footnotetext{
88 A Oy (n 49) para 46.

89 See also A Cordewener, G Kofler and S Van Thiel, The Clash Between European Freedoms and Direct Tax Law: Public Interest Defences Available to the Member States (2009) 46 CML Rev 1974, who argue that in Lidl Belgium (n 49) the Court held that the German refusal to allow the deduction of foreign PE losses was justified by the need to safeguard the balanced allocation of taxing powers and the danger of losses being used twice because the tax treaty allocated tax jurisdiction over the PE profits exclusively to the source state.

90 M Lang, Recent Case Law of the ECJ in Direct taxation: Trends, Tensions and Contradictions (2009) 3 EC Tax Review 109.
} 
attributed to the general particularities of direct taxation and, specifically, the lack of any allocation of taxing powers among the different Member States. Such a 'double taxing jurisdiction' might give rise to (economic and juridical) double taxation and the subsequent need for the allocation of taxing rights. ${ }^{91}$ However, it remains doubtful whether the Court should have the power to allocate such taxing rights in order to eliminate the obstacle of double taxation. While outright discriminatory tax measures should be eliminated, very few national tax measures are currently challenged before the CJEU for being prima facie directly discriminatory. In contrast, the majority of the measures brought forward concern restrictions that emanate from the interaction of two national tax systems.

The unanswered questions in the area of dividends taxation are akin to the compatibility of obstacles arising from the mere interaction of two tax systems with EU law, the different treatment of incoming and outbound dividends, ${ }^{92}$ the choice of the state to provide relief from double taxation (home - host or neither), compatibility with the Treaty method of relief from double taxation (without the possibility of the simultaneous application of both the credit and exemption methods) and subsequently the most desired neutrality to be achieved..$^{93}$

The first 2008 'dividend' case was the Aberdeen case, ${ }^{94}$ where the Court considered whether a Finnish measure that allowed for the exemption of withholding taxes for dividends that were distributed domestically

\footnotetext{
91 Although the Parent Subsidiary Directive (Council Directive 90/435/EEC of 23 July 1990 on the common system of taxation applicable in the case of parent companies and subsidiaries of different Member States) clearly facilitates cross-border dividend payments, it has to be clarified that not all cross-border dividend payments are covered by it. The limitations of the Parent Subsidiary Directive can be summarised by the need of the parent company to hold at least $10 \%$ of the shares in the subsidiary company for the exemption to apply and on the limited applicability to certain types of companies. Whenever national measures do not fall in the scope of the Directive, Member States maintain their power to decide whether and to what extent they want to exercise their taxing rights with respect to the distribution of profits. This power might cause multiple tax burdens which will arise, as will be explained, either by the legislation of a single national tax system which will be discriminating against cross-border situations or by the mere interaction between two different Member States' tax systems. The problem is aggravated because of the silence of the Treaty regarding relief from double taxation. Article 293 TEC which stipulated that 'Member States shall, so far as is necessary, enter into negotiations with each other with a view to securing for the benefit of their nationals: [...] the abolition of double taxation within the Community', was not included in the TFEU.

92 Incoming dividends mean the dividends that leave the 'source' or 'host' state and enter the 'residence' or 'home' state, whereas outbound dividends mean the dividends that leave the 'home' or 'residence' state to enter the 'host' or 'source' state. The case resembles the company case law relating to the free movement to 'enter' and to 'exit'.

93 Neutrality here means either Capital Import Neutrality (CIN) or Capital Export Neutrality (CEN).

94 Aberdeen Property Fininvest Alpha (n 48).
} 
was compatible with the freedom of establishment. The case concerned the distribution of dividends from Aberdeen, a Finland-based company, to a SICAV based in Luxembourg. The comparability of the given domestic situation with the given cross-border one was problematic, as the form of a SICAV company was not recognised by Finnish legislation. In a seemingly desperate effort to establish comparability between the two cases, the Court ruled that 'once a Member State, unilaterally or by way of a convention, imposes a charge to income tax not only on resident shareholders but also on non-resident shareholders in respect of dividends which they receive from a resident company, the position of those non-resident shareholders becomes comparable to that of resident shareholders'. ${ }^{95}$ In line with the 'refined restrictions approach' followed in most of the group relief cases, the Court primarily found a difference in treatment that constituted a restriction of the freedom of establishment, potentially justifiable under justifications based on public interest. With regard to the latter, the Court rejected all the prevention of tax avoidance on the grounds that the measure at issue did not specifically target against wholly artificial arrangements ${ }^{96}$ the balanced allocation of taxing powers on the grounds that in so far as dividends distributed by resident companies are taxed in the hands of the distributing companies as profits realised, the exemption from withholding tax on those dividends does not deprive the Republic of Finland of all right to tax the income relating to activities carried out on its territory', ${ }^{97}$ as well as the need to maintain the coherence of the tax system because of the lack of a direct link between the tax and the offsetting of that advantage by a particular tax levy. ${ }^{98}$

In the Haribo case, ${ }^{99}$ the Court was called to answer whether the Austrian measure that provided that nationally sourced dividends were exempted from tax unconditionally, whereas portfolio dividends from EU/EEA countries could either be exempted or provided with a credit under certain conditions, ${ }^{100}$ was compatible with the free movement

\footnotetext{
95 ibid para 43.

96 See the 'Cadbury doctrine', Case C-196/04 Cadbury Schweppes and Cadbury Schweppes Overseas [2006] ECR I-7995.

97 Aberdeen Property Fininvest Alpha (n 48) para 70: 'in so far as dividends distributed by resident companies are taxed in the hands of the distributing companies as profits realised, the exemption from withholding tax on those dividends does not deprive the Republic of Finland of all right to tax the income relating to activities carried out on its territory'.

98 Case C-484/93 Svensson and Gustausson [1995] ECR I-3955, para 18; Imperial Chemical Industries plc (ICI) $v$ Kenneth Hall Colmer (Her Majesty's Inspector of Taxes) (n 12) para 29; Manninen (n 41) para 42; and Keller Holding (n 55) para 40.

99 Haribo Lakritzen Hans Riegel and Österreichische Salinen (n 48).

100 Exemption for 'foreign' portfolio dividends would be provided if comparability to domestic corporations falling within the scope of para 7(3) could be established and comprehensive procedures existed between Austria and EU/EEA Member States for mutual assistance with regard to administrative and enforcement matters, whereas credit would be provided if the taxpayer submitted a declaration containing information about the
} 
of capital. The crucial question the Court attempted to address was whether the exemption and imputation methods, as methods of relief from double taxation, should be considered as equivalent. The Court ruled that the existence of an additional condition for relief rendered investment abroad less attractive, and thus the measure was restrictive of the free movement of capital. Similar to the A Oy case, ${ }^{101}$ the Court started its analysis by deploying an 'obstacles-based' analysis to review the comparability of situations as a quasi justification: a corporate shareholder receiving foreign sourced dividends was comparable ${ }^{102}$ to a corporate shareholder receiving nationally sourced dividends. ${ }^{103}$ Since the two situations were deemed comparable, the restriction could only be justified on public interest justifications (and thus not on Article 65(1) TFEU). ${ }^{104}$ The Court accepted this time that both the effectiveness of fiscal supervision and the prevention of tax avoidance arguments were able to justify the restrictive measure, on the grounds that

where the legislation of a Member State makes the grant of a tax advantage dependent on satisfying conditions compliance with which can be verified only by obtaining information from the competent authorities of a non-member State party to the EEA Agreement, it is in principle legitimate for the Member State to refuse to grant that advantage if - in particular, because that non-member State is not bound under an agreement to provide information - it proves impossible to obtain the requisite information from it (Établissements Rimbaud, paragraph 44). ${ }^{105}$

company and the actual tax base and rate the company was subject to. If none of the aforementioned conditions applied no relief would be provided.

101 A Oy (n 49).

102 Note here the different distinction and opinion of AG Kokott, according to whom the situations were not comparable with regard to the method of preventing double taxation to be used because the unconditional exemption was not capable of guaranteeing that corporation tax was also levied on foreign dividends at the domestic level (para 44 of the AG's Opinion) (emphasis added). Thus, Art 65(1)(a) TFEU could apply as a justification.

${ }^{103}$ Para 59: in the context of a tax rule, such as that at issue in the main proceedings, which seeks to prevent the economic double taxation of distributed profits, the situation of a corporate shareholder receiving foreign sourced dividends is comparable to that of a corporate shareholder receiving nationally sourced dividends in so far as, in each case, the profits made are, in principle, liable to be subject to a series of charges to tax (see Test Claimants in the FII Group Litigation (n 8) para 62).

${ }^{104}$ Art 65 (1) TFEU mainly stipulates that different tax treatment is allowed for taxpayers who are not in the same position with regard to their place of residence and the place where their capital is invested. The derogation in that provision is itself limited by Article 65(3) TFEU, which provides that the national provisions referred to in Article 65(1) 'shall not constitute a means of arbitrary discrimination or a disguised restriction on the free movement of capital and payments as defined in Article 63'.

${ }^{105}$ Haribo Lakritzen Hans Riegel and Österreichische Salinen (n 48) para 67. 
The Court in the Haribo case was asked to reconsider its case law with regard to international juridical double taxation. As expected, the CJEU confirmed its earlier, settled case law ${ }^{106}$ according to which 'dividends distributed by a company established in one Member State to a shareholder resident in another Member State are liable to be subject to juridical double taxation where the two Member States choose to exercise their fiscal competence and to subject those dividends to taxation in the hands of the shareholder' and continued by noting that 'the Court has already ruled that the disadvantages which may arise from the parallel exercise of powers of taxation by different Member States, in so far as such an exercise is not discriminatory, do not constitute restrictions prohibited by the Treaty'. ${ }^{107}$ Since European Union law, as it currently stands, does not lay down any general criteria for the attribution of areas of competence between the Member States in relation to the elimination of double taxation within the European Union, the fact that both the Member State in which the dividends are paid and the Member State in which the shareholder is resident are liable to tax those dividends does not mean that the Member State of residence is obliged, under European Union law, to prevent the disadvantages which could arise from the exercise of competence thus attributed by the two Member States. ${ }^{108}$ The Court, thus, by applying a 'per country approach', adhered to its settled distinction between economic and juridical double taxation. By answering the question of whether or not international juridical double taxation caused by the parallel exercise of tax competences by different Member States infringes the fundamental freedoms of the TFEU in the negative, the Court provided a regrettable outcome, at least from the perspective of the internal market. Such a result remains, however, understandable considering that, had the CJEU decided otherwise, it would have subsequently had to decide which Member State would be responsible (and to what extent) for removing the double taxation. ${ }^{109}$ On the other hand, the grounds on which the CJEU maintains this distinction, as if econo-

106 Case C-513/04 Kerckhaert and Morres [2006] ECR I-10967, para 22; Orange European Smallcap Fund (n 48); Damseaux (n 44) para 33; Case C-67/08 Block [2009] ECR I-883, para 30; Case C-96/08 CIBA [2010] ECR I-0000, paras 27 and 28.

107 Damseaux (n 44) paras $26-27$.

108 Haribo Lakritzen Hans Riegel and Österreichische Salinen (n 48) paras 168-169; Case C-487/08 Commission v Spain [2010] ECR I-0000, paras 56 and the case law cited.

109 To this extent, see inter alia, Dennis M Weber, 'In Search of a (New) Equilibrium Between Tax Sovereignty and the Freedom of Movement Within the EC' (2006) Intertax 593. For a view advocating that international juridical double taxation is contrary to the fundamental freedoms, see Frans Vanistendael, 'Does the ECJ have the Power of Interpretation to Build a Tax System Compatible with the Fundamental Freedoms?' (2008) EC Tax Review 52, 66, who takes the view that obstacles resulting from double burdens caused by the cumulative application of disparate non-discriminatory tax rules in two different Member States also constitute a restriction on the free movements and thus, in principle, are incompatible with the fundamental freedoms. 
mic double taxation is more detrimental to the freedoms in comparison to juridical double taxation, still remain puzzling. ${ }^{110}$

In the Accor case, ${ }^{111}$ France's reference for a preliminary ruling asked the Court to rule on whether the provision of tax credit against advanced payment (ACT) upon dividend redistribution to shareholders when the subsidiary of the parent is established in France, but not when the subsidiary of the parent is in another Member State (no entitlement to tax credit), was contrary to EU Law. The Court considered the comparability of the two situations as a potential justification and ruled, inter alia, that by treating nationally sourced dividends more favourably than foreign sourced dividends, French law introduced a difference in treatment (per country approach). It specifically noted that '[i]t is common ground that the rules at issue introduce a difference in treatment between dividends distributed by a resident subsidiary and those distributed by a non resident subsidiary"112 which might dissuade a parent company 'from carrying on its activities through the intermediary of subsidiaries established in other Member States'. ${ }^{113}$ The Court found that 'the difference in treatment depending on the place of establishment of the subsidiary distributing the dividends and the possibility of setting off any tax credit against the advance payment due when those dividends were redistributed, stemmed directly from the French legislation at issue in the main proceedings'. ${ }^{114}$ Since France did not provide for any justifications, the Court stopped its reasoning in simply finding a 'discriminatory restriction' on behalf of France, by applying a 'per country' approach.

In the Test Claimants FII case, ${ }^{115}$ the UK asked the Court to elabo-

\footnotetext{
110 The Court has, on several occasions, ruled that economic double taxation infringes the free movements. See, for instance, Case C-315/02 Lenz [2004] ECR I-7063, paras 20 to 49; Manninen (n 41) paras 20 to 55; and Test Claimants in the FII Group Litigation (n 8) para 46.

111 Case C-310/09 Accor SA [2011] ECR I-0000.

112 ibid para 44: It is thus clear from the case law that, whatever the mechanism adopted for preventing or mitigating the imposition of a series of charges to tax or economic double taxation, the freedoms of movement guaranteed by the Treaty preclude a Member State from treating foreign sourced dividends less favourably than nationally sourced dividends, unless such a difference in treatment concerns situations which are not objectively comparable or are justified by overriding reasons in the public interest (see, to that effect, Case C-315/02 Lenz [2004] ECR I-7063, paras 20 to 49; Manninen (n 41) paras 20 to 55; and Test Claimants in the FII Group Litigation (n 8) para 46).

113 Accor $S A$ (n 111) para 51.

114 ibid para 58.

115 Case C-35/11 Test Claimants in the FII Group Litigation [2012] ECR I-0000. The case poses questions relating to the 'first FII case'. In the first FII case (Test Claimants in the FII Group Litigation (n 8)), the CJEU addressed a number of issues relating to the UK tax treatment of dividends received from foreign companies. A key issue was whether the UK was in breach of EU law by exempting dividends received from resident companies, while taxing dividends from comparable foreign companies, and providing a credit for underlying foreign tax. The CJEU held that, in principle, the UK was not in breach of EU law provided the foreign profits were not subject to a higher tax rate than domestic dividends. The cur-
} 
rate on the equivalence of the imputation and the exemption methods for providing relief from double taxation. ${ }^{116}$ On comparability grounds, the Court held that a corporate shareholder receiving foreign sourced dividends is comparable to a corporate shareholder receiving nationally sourced dividends, in so far as, in each case, the profits made are, in principle, liable to be subject to a series of charges to tax. As such, the Court continued, a need for equal treatment when providing relief from double taxation arose. Such equal treatment was, however, not provided, since nationally sourced dividends were exempted from double taxation, whereas foreign sourced dividends were provided with a credit. ${ }^{117}$ The Court applied once again the 'refined test' as it first researched whether the two situations were comparable, before it proceeded to establish a difference in treatment and, thus, a restriction in the free movement of capital and establishment. ${ }^{118}$ Along the pattern re-established pursuant to the Krankheim judgment, the measure was found justifiable on the grounds of the cohesion of the tax system, as the Court identified the existence of a direct link between the tax levy (the tax the distributed profits have already been subject to) and the tax advantage of the provision of credit and exemption. In this way, the Court found the economic double taxation of the distributed profits was avoided. The UK measure at issue failed, however, to pass the proportionally test, as it fell short of the necessity limb. The CJEU ruled that it was not necessary, in order to maintain the cohesion of the tax system in question, to take account of the effective level of taxation to which the distributed profits have been subject to calculate the tax advantage when applying the imputation met-

rent referral seeks guidance on how to interpret this exception. Another important issue concerned whether a UK resident company receiving dividends from a third country on the basis of a holding which gives the receiving company definite influence over the decisions of the company making the distribution falls within the scope of the free movement of capital. The referral also dealt with certain aspects of the UK's former ACT regime. Because of their specific nature, these are not covered here.

${ }^{116}$ A summary of the question that arose in Test Claimants in the FII Group Litigation (n 115). The question asked, in principle, whether the fact that nationally sourced dividends were exempted from corporation tax whereas foreign sourced dividends were granted credit relief against the withholding tax paid at source contravened Arts 49 and 63 TFEU. The 'new' FII referred 4 more questions to the CJEU by reference to the original case, which, in view of their being unrelated to the issues under consideration here, will not be presented in this section.

117 Test Claimants in the FII Group Litigation (n 115) para 65 '[...] the answer to the first question is that Articles 49 TFEU and 63 TFEU must be interpreted as precluding legislation of a Member State which applies the exemption method to nationally-sourced dividends and the imputation method to foreign-sourced dividends if it is established, first, that the tax credit to which the company receiving the dividends is entitled under the imputation method is equivalent to the amount of tax actually paid on the profits underlying the distributed dividends and, second, that the effective level of taxation of company profits in the Member State concerned is generally lower than the prescribed nominal rate of tax'.

118 Test Claimants in the FII Group Litigation (n 115) paras 48-54. 
hod and, on the other hand, of only the nominal rate of tax chargeable on the distributed profits when applying the exemption method. ${ }^{119}$

In the Beker case, ${ }^{120}$ the referring Court's question mainly asked whether it was contrary to the free movement of capital for special personal deductions to be taken into account when calculating the tax credit for withholding tax paid abroad. ${ }^{121}$ The German measure at issue thus stipulated that resident taxpayers benefited completely from the (German) personal and family allowances when all their income was received in Germany, whereas resident taxpayers who had received part of that income abroad were not entitled to such complete benefits. While the CJEU did not explicitly consider the comparability of the two situations, it ruled that:

taxpayers resident in one Member State who have received one part of their revenue abroad are at a disadvantage compared with taxpayers resident in the same Member State who received all of their revenue in that Member State and who therefore benefit from all allowances corresponding to special costs and extraordinary charges such as costs relating to lifestyle or to personal and family circumstances. Consequently, such a difference in treatment is likely to discourage persons subject to unlimited taxation in a Member State from investing their capital in companies having their principal place of business in another Member State or in a third State. ${ }^{122}$

While the comparability element, inherent in the discrimination test, is only implicitly acknowledged, the case should also be classified as a 'refined restrictions approach' case because of the attempt to establish 'difference in treatment' before finding 'discouragement', 'dissuasion', 'obstacle' or 'restriction'. The only justification put forward by the Ger-

\footnotetext{
${ }^{119}$ Nominal taxation is usually higher than the effective levels (higher tax base).

${ }^{120}$ Case C-168/11 Beker [2013] (nyr).

${ }^{121}$ As the dividend income of individuals is (partly) taxable, the foreign withholding tax can - in accordance with the underlying double tax treaty and Sec 34c Income Tax Act - be credited against the respective amount of German income tax. However, when assessing the respective amount of tax, special personal expenses without any link to the foreign income will partly be attributed to this income. This attribution reduces the taxable foreign income and thus results in a limitation of the tax credit. The referring Court's question thus mainly asks whether it is contrary to the free movement of capital for special personal deductions to be taken into account when calculating the tax credit for withholding tax paid abroad. If special personal deductions were allowed to affect the tax credit, the risk of juridical double taxation of dividends would arise, while personal tax allowances would not come totally into effect. Under the conventions for the avoidance of double taxation, concluded between the Federal Republic of Germany and the States of origin of those dividends, it is open to that Member State, as the State of residence of the applicants in the main proceedings, to levy a tax on foreign dividends. In order to avoid juridical double taxation of those dividends, foreign withholding tax is offset against the income tax due according to the income tax scale, up to the level of the German income tax charged on the income concerned.

${ }^{122} \operatorname{Beker}$ (n 120) paras 51-52.
} 
man government that Germany was not obliged to compensate for disadvantages linked to the failure to take into account the taxpayers' personal circumstances during the taxation of foreign income in the source state was not accepted by the Court. The grounds for the Court not to accept this were that the taxpayer's state of residence could not use the justification of the balanced allocation of taxing powers in order to evade its responsibility to grant the taxpayer the personal and family allowances to which he is entitled, unless, of their own accord or as a consequence of specific international agreements, the states in which one part of the income is received grant such allowances. ${ }^{123}$

\subsection{Comment}

Although from the presentation of the aforementioned cases no clear patterns can be seen, we can observe a more lenient approach of the Court towards the Member States' tax systems, in particular in comparison to the early years. This more lenient approach is expressed through the Court's maintenance of the comparability test, inherent in the establishment of discrimination, in order to find unequal treatment and thus a 'discriminatory restriction'. Thus, not all tax measures can be swept under an 'all-encompassing market access test'.

The comparability test is in most cases assessed under the aim of the measure test ${ }^{124}$ and despite the settled case law that residents and non-residents are not in comparable situations, in recent cases the Court seems to adhere to a much more 'instrumental use' of a new comparability test according to which

once a Member State, unilaterally or by way of a convention, imposes a charge to income tax not only on resident shareholders but also on non resident shareholders in respect of dividends which they receive from a resident company, the position of those non-resident shareholders becomes comparable to that of resident shareholders. ${ }^{125}$

Under the 'new comparability test', ${ }^{126}$ the Court seems to attempt an allocation of taxing competences between the Member States, an issue

\footnotetext{
123 ibid para 56.

${ }^{124}$ See Metallgesellschaft and Others (n 43) para 60; Case C-231/05 Oy AA [2007] ECR I-6373, para 38; Orange European Smallcap Fund (n 48).

125 Aberdeen Property Fininvest Alpha (n 48) para 43.

${ }^{126}$ With regard to the possibility of two situations being comparable 'as long as (cc the subjects/objects at issue) are subject to tax', see also Test Claimants in the FII Group Litigation (n 116) and Haribo Lakritzen Hans Riegel and Österreichische Salinen (n 48) para 59: [...] the situation of a corporate shareholder receiving foreign-sourced dividends is comparable to that of a corporate shareholder receiving nationally-sourced dividends in so far as, in each case, the profits made are, in principle, liable to be subject to a series of charges to tax. With regard to the possibility of two situations being comparable "as long as (cc they are) subject to tax"'.
} 
that resembles to a great extent the justification accepted by the Court, in various cases, of the balanced allocation of taxing powers.

With reference to relief from double taxation - and the choice of the (most) compatible with EU law, the relief method - the CJEU has persisted in trying to allocate taxing powers between Member States in the context of economic double taxation so as to ensure that economic double taxation is eliminated by one of the states, while it keeps renouncing such competence with respect to juridical double taxation. ${ }^{127}$ As such, the Court seems to adopt - to a much larger extent than before - the per country approach, in particular with regard to juridical double taxation, whereby the restriction at issue is not caught by the four freedoms if the difference in treatment does not stem from one Member State's legislation. ${ }^{128}$

At the same time, the resurrection and the more frequent use of the fiscal cohesion principle, ${ }^{129}$ as well as the clarification that the justifications of the balanced allocation of taxing powers, the risk of tax avoidance and the danger of double dip can be advanced separately, ${ }^{130}$ seem to provide governments with more opportunities to justify the 'discriminatory restrictions' arising from their tax systems.

The last part of the analysis, the two-pronged proportionality test, leaves the Court with too much room for manoeuvring. The rejection of less restrictive measures like the deduction recapture rule in the $\mathrm{X} \mathrm{Hol}$ ding judgment ${ }^{131}$ shows first that the Court can easily direct via the proportionality test the outcome of the judgment and that, occasionally, it does not trust the exchange of information mechanisms, like the Mutual Assistance Directive, ${ }^{132}$ between the Member States.

In view of the lack of clarity and often the inconsistency of the judgments in this area, the legal reasoning employed by the Court seems to be 'adjustable' in accordance with the desirable outcomes of the judgment. From an outcomes' perspective, the CJEU's decisions can

\footnotetext{
${ }^{127}$ See Englisch (n 45) 214 and the references listed therein. See also Haribo Lakritzen Hans Riegel and Österreichische Salinen (n 48).

${ }^{128}$ Krankenheim Ruhesitz am Wannsee-Seniorenheimstatt (n 49); Haribo Lakritzen Hans Riegel and Österreichische Salinen (n 48).

${ }_{129}$ Krankenheim Ruhesitz am Wannsee-Seniorenheimstatt (n 49); Test Claimants in the FII Group Litigation (n 115).

130 These three justifications comprised the three pack of successful justifications in the Marks and Spencer case (n 6), but as specified by the Court in this case when taken together'.

131 Similarly Lidl Belgium (n 49).

132 Council Directive (EU) 2011/16 of 15 February 2011 on the administrative cooperation in the field of taxation and repealing Council Directive (EEC) 77/799 of 19 December 1977 on the mutual assistance by the competent authorities of Member States in the field of direct taxation and taxation of insurance premiums.
} 
have tremendous implications not only directly for the integrity of the budget but also for the recovery of taxes by the Member States. In a framework where cross-border mobility is enhanced, besides the national tax administrations' tasks to monitor the collection of taxes, the Court can also have a say as to how much 'space' is allowed to the Member States to collect their taxes.

A very important parameter in the recovery of taxes, and a safeguard against tax evasion, is the possibility of the withholding tax raised in the source state (where the income arises) and later passed on to the 'residence state' where the beneficial owner of the income/capital at issue resides. Withholding taxes guarantee that the income of residents arising in another Member State will eventually be made subject to effective taxation in accordance with the laws of the 'residence' Member State. As such, withholding taxes function as rules assisting in the recovery of taxes in transnational situations.

The dividends taxation case law as presented here points in the direction that (resident) Member States are not allowed much leeway in their recovery of taxes. ${ }^{133}$

Similarly, by reference to the 'group losses' regime, when Member States are forced to recognise the right for a consolidation of the transnational losses within an EU group, in certain circumstances ${ }^{134}$ the revenue consequences of this extension can be of paramount importance, directly impinging upon the national budgets.

All in all, no tremendous change - in comparison to the post-2005 case law - can be identified in the Court's legal reasoning and in the outcomes of the cases. In none of the aforementioned cases has the risk of serious economic repercussions and budgetary disturbances been brought forward, so it remains unclear whether the Court has been affected by economic considerations in the cases where it found the national measures compatible with EU law.

A simple observation of the outcomes of these judgments shows that out of the 10 cases briefly assessed, 3 cases were 'won' by the Member States, 6 were lost and one remains to be decided by the national courts. While these data are certainly not conclusive, they are enough to demonstrate that the Court has not returned to the pre-2005 era. It is, at the same time, noteworthy that none of the analysed cases dealt with tax measures introduced because of or as a result of the crisis, a fact that could have potentially triggered different outcomes in the judgments. The

\footnotetext{
${ }_{133}$ Aberdeen Property Fininvest Alpha (n 48); Test Claimants in the FII Group Litigation (n 116); Case C-168/11 Beker [2013] (nyr).

${ }^{134}$ Krankenheim Ruhesitz am Wannsee-Seniorenheimstatt (n 49); X Holding (n 65).
} 
positive stance towards the Member States' tax sovereignty (and budgets) remains and is most often expressed in the application of the more refined non-discrimination approach and in the 'broadening' of the justifications scope.

\section{Budgetary concerns and the CJEU's case law in light of the finan- cial crisis}

Another way the Court could be more 'lenient' towards the Member States would be by employing the mechanism of the limitation of the temporal effects of a judgment. ${ }^{135}$ The current crisis, together with the tremendous budgetary implications a direct taxation judgment might have for the Member States, would call for a broader interpretation of the limitation of temporal effects in the more recent judgments, and in particular with regard to the Member States most affected by the crisis. Thus, on the one hand, the possibility of making the retrospective effect of the Court's tax decisions conditional upon their budgetary consequences would promote efficiency and the rule of law, but on the other hand it would risk rendering the Court a political and policy making institution, guided by economic considerations.

The limitation of the temporal effects of a judgment has been a very useful tool, albeit of limited application in the case law of the CJEU. It can be considered as an apparatus in the hands of the judges that allows them to deliver politically and economically acceptable solutions without the risk of traumatising the integrity of the judicial outcome. While the retroactivity of the Court's judgments is a general rule, ${ }^{136}$ the limitation of the temporal effects of the judgment was developed by the Court as a political choice, since the Treaties do not provide for a legal basis for such an action. The Court set out for the first time the criteria for the granting of this limitation in 1976, in Defrenne, ${ }^{137}$ a case on the equal salaries of men and women.

\footnotetext{
135 See Case C-475/03 Banca popolare di Cremona [2006] ECR I-9373, Opinion of AG Jacobs, 74; Case C-184/99 Grzelczyk [2001] ECR I-6193, para 52; Case C-209/03 Bidar [2005] ECR I-2119, para 68.

136 Case 61/79 Denkavit italiana [1980] ECR 1205, para 16; Case C-66/79 Salumi [1980] ECR 1237, para 9; Case C- 294/99 Athinaiki Zythopoiia AE [2001] ECR I-6797, para 35; Case C-209/03 Dany Bidar [2005] ECR I-2119, para 66: 'It is settled case-law that the interpretation which, in the exercise of the jurisdiction conferred upon it by Article 234 EC, the Court of Justice gives to a rule of Community law clarifies and defines where necessary the meaning and scope of that rule as it must be or ought to have been understood and applied from the time of its entry into force. It follows that the rule as thus interpreted may, and must, be applied by the courts even to legal relationships arising and established before the judgment ruling on the request for interpretation, provided that in other respects the conditions enabling an action relating to the application of that rule to be brought before the courts having jurisdiction are satisfied'.

137 Case C-43/75 Defrenne v Sabena (Defrenne II) [1976] ECR 455.
} 
The Court has repeatedly held that it is only in exceptional cases that the effects of a judgment on a request for interpretation may be limited. Such a step may be taken, the Court argues, only in certain specific circumstances, for instance where

there is a risk of serious economic repercussions owing in particular to the large number of legal relationships entered into in good faith on the basis of rules considered to be validly in force, and where it appears that both individuals and national authorities have been prompted to adopt practices which do not comply with Community law by reason of objective, significant uncertainty regarding the implications of Community provisions, to which the conduct of other Member States or the Commission may even have contributed. ${ }^{138}$

In subsequent judgments the Court clarified that two criteria must be (cumulatively) satisfied for the limitation of temporal effects to apply: the State (and/or private parties) must have acted in good faith that their measures at issue did not violate EU law and that there is a 'risk of serious difficulties'. ${ }^{139}$

With the exception of the enhancement of legal certainty and predictability, the 'prospective overruling' of the CJEU's cases certainly has its shortcomings. On the one hand, it allows the Member States to maintain 'discriminatory' or 'restrictive' laws since the budgetary risk if they get 'caught' will be minimal. In addition, as AG Saggio has observed, non-retroactivity on account of the extent of the financial repercussions on Member States would have the paradoxical consequence of treating the most serious infringements more favourably than those of a less serious nature, the former being obviously those which are likely to have the most significant financial implications for Member States. ${ }^{140}$ Finally, prospective overruling could be considered as incompatible with the judicial role itself, which is to state what the law is and not to prescribe what it shall be. ${ }^{141}$

Since the purpose of this subsection is not to analyse the limitation of temporal effects in general, but to research how the budgetary impli-

\footnotetext{
138 Joined Cases C-197/94 and C-252/94 Bautiaa [1996] ECR I-505, para 38.

139 See Case C-475/03 Banca popolare di Cremona [2006] ECR I-9373, Opinion of AG Jacobs, 74; Case C-184/99 Grzelczyk [2001] ECR I-6193, para 52; Case C-209/03 Bidar [2005] ECR I-2119, para 68; Case C-57/93 Vroege [1994] ECR I-4541, para 21: 'Exceptionally, however, having regard to the need for legal certainty, the Court may limit the possibility for parties to rely on the interpretation in such a judgment to call in question legal relations established in good faith in the past. Before deciding to impose such a limitation, it verifies that two essential criteria are fulfilled, namely that those concerned should have acted in good faith and that there should be a risk of serious difficulties' (emphasis added).

140 Case C-437/97 Evangelischer Krankenhausverein Wien (EKW) v Abgabenberufungskommission Wien [2000] ECR I-1157, Opinion of AG Saggio, para 65.

${ }^{141}$ US Supreme Court Justice Scalia cited in Jill Fisch, 'Retroactivity and Legal Change: An Equilibrium Approach' [1997] 110 Harvard Law Review 1055.
} 
cations of the Court's judgments might have an impact on the Court's choices, we will focus more on the latter criterion and less on the element of 'good faith'.

As a starting point, it is evident that the economic consequences and the result of 'a risk of serious difficulties' differ from Member State to Member State. Since the CJEU is willing to limit the temporal effects of a judgment only if its economic repercussions are severe for the Member State at issue, an ad hoc analysis considering the public financial condition of each Member State at issue is necessary, ${ }^{142}$ and no 'one size fits all' approach can apply. The limited territorial effects the limitation of retrospectivity can have for other Member States has been confirmed by AG Stix-Hackl in her opinion in Banca Popolare di Cremona. ${ }^{143}$

Despite the view confirmed in settled case law that the Court cannot accept the loss of tax revenue as a justification for a restrictive (or discriminatory) measure, ${ }^{144}$ there is evidence that the CJEU is aware of the pressure its decisions might have on national budgets. In the excise duties $E K W$ case,${ }^{145}$ the amount at stake was estimated to be the equivalent of $€ 1.6$ billion. Although AG Saggio argued that taking budgetary consequences into account would reduce the Court's competence in tax matters to trivial issues, ${ }^{146}$ the Court decided otherwise. It accepted the Austrian government's good faith, while it indirectly translated the budgetary argument as a 'serious difficulty':

\footnotetext{
${ }^{142}$ Michael Lang, 'Limitation of the Temporal Effects of Judgments of the ECJ' (2007) 35 Intertax 230, 237.

${ }^{143}$ Case C-475/03 Banca popolare di Cremona [2006] ECR I-9373, Opinion of AG StixHackl, 179ff: "If a temporal limitation is imposed on the effect of such a ruling, it will be in the interest of the Member State concerned, in order to avoid exceptional disruption. If there is an exception to the limitation it will be granted, by contrast, in the interests of those who, within the Member State, have sought to assert claims in reliance on Community law. Yet a ruling on interpretation has general effect. If the Court rules that a tax having the characteristics of IRAP as described by the referring court is incompatible with the Sixth Directive, that will be true for IRAP and equally true for any other tax having those characteristics in any other Member State. However, any temporal limitation and any exception thereto decided upon by the Court will be based on an assessment of the situation - existence of good faith on the part of the State, risk of serious disruption for the State and need for effective judicial protection of diligent claimants - in Italy, and that assessment might be quite different with regard to another Member State which also applied a tax having the same characteristics. That consideration implies that any limitation should be not only temporal but also, in effect, spatial - a point of some relevance in the present case since it appears from several of the numerous articles which have already appeared in legal and tax journals concerning this case that one or more Member States other than Italy may apply taxes which, at least in the opinion of some authors, share certain characteristics with IRAP' (emphasis added).

144 Case Verkooijen (n 43) para 59; Case Manninen (n 41) para 49.

145 EKW and Wein \& Co (n 140).

${ }^{146} E K W$ and Wein \& Co (n 140) Opinion of AG Saggio, para 65.
} 
In those circumstances, and without there being any need to consider the global amount in question, the absence of proof of payment or the very large number of small transactions concerning small amounts, overriding grounds of legal certainty preclude calling in question legal relations which have exhausted their effects in the past; to do so would retroactively cast into confusion the system whereby Austrian municipalities are financed. ${ }^{147}$.

The likely confusion ${ }^{148}$ and the administrative burden that might arise from the many repayments the Austrian state would have to make seem too weak to justify (alone) the Court's decision. Hence, it seems unconvincing that the Court reached this decision while ignoring the tremendous amount at stake.

The order to reopen the oral procedure, including the delivery of a new Advocate General's opinion in two key tax cases ${ }^{149}$ where the amounts of refund at stake could be enormous, also tells of the Court's stance towards the budgetary implications of its judgments. ${ }^{150}$ The first case, Banca Popolare di Cremona, ${ }^{151}$ concerned an indirect tax measure, which, if found incompatible with EU law, would have cost the Italian government $€ 120$ billion. ${ }^{152}$ Thus, it is not by chance that the case - decided in the Grand Chamber - attracted 15 (!) intervening Member States.

In the first opinion, issued in March 2005, AG Jacobs acknowledged the difficulty of deciding on the limitation of the temporal effects of the judgment, as well as its extent. ${ }^{153}$ In the second opinion delivered on this case, AG Stix-Hackl acknowledged the need for a 'nuanced' limitation of the temporal effects of this judgment and thus, proposed:

\footnotetext{
${ }^{147}$ EKW and Wein \& Co (n 140) para 59 (emphasis added).

148 The confusion criterion was also used in Case C-262/96 Sürülv Bundesanstalt fur Arbeit [1999] ECR I-2685, where, the Court found that the retrospective application of its decision would 'retroactively throw the financing of the social security systems of the Member States into confusion' (para111), thus accepting the point raised by Member States that the effect of a retrospective judgment 'would be such as to undermine a large number of legal relationships established on the basis of national legislation which has been in force for some time and to have serious financial repercussions for the social security systems of the Member States' (para 106).

149 Case C-475/03 Banca popolare di Cremona [2006] ECR I-9373 and Case C-292/04 Meilicke and Others [2007] ECR I-1835.

${ }^{150} \mathrm{M}$ O'Brien, 'Direct Taxation, the ECJ and Implications for Member State Budgets' in A Verdun (ed), Political and Economic Consequences of Economic and Monetary Union: Taking Stock of the First Eight Years (Nova Science Publishers Inc 2007) 208.

151 Banca popolare di Cremona (n 149).

152 ibid para 72.

153 Banca Popolare di Cremona v Agenzia Entrate Ufficio Cremona (n 149) Opinion of AG Jacobs, para 87: 'In view of the difficulties involved in choosing the appropriate limitation, it may be desirable for the Court to reopen the oral procedure to hear further argument on that point'.
} 
The prohibition in that article may not be relied upon in order to claim reimbursement of IRAP levied in respect of any period of assessment prior to the Court's judgment, or in respect of the period during which that judgment is delivered, except by persons who initiated legal proceedings or raised an equivalent administrative claim before 17 March 2005, the date on which Advocate General Jacobs delivered his Opinion in the present case. Such claimants may rely on it to the extent that their claims are not otherwise barred by national procedural rules which observe the principles of equivalence and effectiveness. ${ }^{154}$

The Court, in its turn, found that the measure at issue was compatible with Article 33 of the $6^{\text {th }}$ VAT Directive, and hence it did not touch upon the question of the limitation of the temporal effects.

In the Meilicke case, ${ }^{155}$ Germany's tax refund liability was estimated at $€ 5$ million. ${ }^{156}$ In the first opinion AG Tizzano delivered in November 2005, he suggested that the judgment should have effect from the date the CJEU ruled in Verkooijen, ${ }^{157}$ as that was the time when the stance of EU law towards dividend taxation became clear, implying that until then Germany was acting in good faith. ${ }^{158}$

In the second opinion in the Meilicke case, AG Stix-Hackl considered that Germany did not provide for sufficient evidence of the risk of serious economic repercussions, ${ }^{159}$ whereas it was also suggested that Germany was not acting in good faith while denying cross-border relief for EU dividends, in particular after the judgments in the Verkooijen and Manninen cases. ${ }^{160}$ The AG, along the lines of the reasoning of AG Saggio, noted that in the absence of a de minimis rule, a clear (quantifiable) test

\footnotetext{
${ }^{154}$ Banca Popolare di Cremona v Agenzia Entrate Ufficio Cremona (n 149) Opinion AG StixHackl, para187.

155 Meilicke and Others (n 149)

156 This was the estimation of the German government in the first hearing. During the second hearing the German government attempted unsuccessfully to exaggerate this amount. 157 Verkooijen (n 43).

158 Meilicke and Others (n 149) Opinion of AG Tizzano, para 47: 'It should be noted that, with regard to a limitation on the temporal effect of a judgment, "the Court has consistently held [that] such a restriction may be allowed only in the actual judgment ruling upon the interpretation sought". However, that would not apply in the present case since, as I have pointed out more than once, the interpretation of the Community rules from which it follows that the German legislation at issue in the present case is unlawful is based essentially on the judgment in Verkooijen and a limitation of the temporal effect of that judgment was neither requested nor automatically granted.'

159 Meilicke and Others (n 149) Opinion of AG Stix-Hackl, para 57ff.

160 ibid para $45 \mathrm{ff}$.
} 
should not be encouraged, ${ }^{161}$ a view that was endorsed in literature. ${ }^{162}$ The Court, however, missed the opportunity to elaborate further on the degree of the severity of the financial repercussions and the possible budgetary implications and their relation to the granting of 'prospectivity'. In a rather short and unsatisfactory part of the judgment, it rejected the plea for a limitation of the temporal effects of the judgment, by referring to the Verkooijen ${ }^{163}$ and Manninen ${ }^{164}$ cases. It noted that the requirements arising from the free movement of capital in respect of dividends received by residents from non-resident companies were clarified in the two aforementioned judgments, ${ }^{165}$ thus implicitly excluding the possibility of Germany acting in good faith after these two cases were decided, while it added that the Court did not limit the temporal effects in these previous judgments either. ${ }^{166}$

The opinion of AG Stix-Hackl had been preceded by the opinion of AG Geelhoed in April 2006 in the Test Claimants FII case. ${ }^{167}$ The latter also adopted a more moderate approach towards the granting of prospectivity, as requested by the UK during the oral submissions. The plea was rejected on the basis that it was insufficiently substantiated. The Advocate General pointed to another 'thorn' in the granting of limitation of temporal effects, the often inaccurate estimation of the economic damages. The mere reference to the 'catastrophic consequences of a judgment' is not, therefore, sufficient, and specific proof should be provided with regard to the budgetary consequences in order to substantiate the plea for prospectivity. AG Geelhoed noted that although the figure at stake was put at $£ 7$ billion by the defendant, the UK Government 'gave no indication of how it arrived at this figure'. ${ }^{168}$ The same cautious approach ${ }^{169}$ was

\footnotetext{
161 ibid para 60: The risk of serious economic repercussions may not be established solely by reference to figures, but requires an assessment by the Court based upon the submissions of facts of the Member State which made the application. Accordingly, in my view, the Court should resist the temptation to link the degree of severity of the financial repercussions to the level of the possible financial consequences or specific sums of money. Even taking into account the varying economic strength of the various Member States, I think it is dangerous to proceed in the long term on the basis that specific (even if large) amounts of money imply a risk of serious economic repercussions from the outset. This would seem to me to be putting the cart before the horse and could even, in the worst case scenario, lead to a "threshold value discussion"' (emphasis added).

162 Otmar Thömmes, 'European Legal Order with no Mercy for Member States' Budget Concerns' (2007) 35 Editorial Intertax 3; Lang (n 142) 230.

163 Verkooijen (n 43).

164 Manninen (n 41).

165 Meilicke and Others (n 149) para 40.

166 ibid paras 37-39.

167 Test Claimants in the FII Group Litigation (n 8).

168 Test Claimants in the FII Group Litigation (n 8), Opinion of AG Geelhoed, para 144.

169 Test Claimants in the Thin Cap Group Litigation (n 34), Opinion of AG Geelhoed, para 112: 'In any event, as I observed in my Opinion in the FII case, it is for the UK, when raising a
} 
applied in the Thin Cap Group Litigation, ${ }^{170}$ a group relief case where the sum at issue was estimated at $€ 300$ million, but no evidence was provided as to how the UK government reached this estimation.

It follows that so far the Court seems to adopt a rather moderate approach with regard to the limitation of temporal effects. In cases where the amounts at stake were particularly large, exceeding $€ 1$ billion, the Court either abstained from issuing an opinion, as it found the measure at issue compatible with EU Law (Banca Popolare di Cremona ${ }^{171}$ ), or granted the limitation of the temporal effects of the judgment (the $E K W$ case). ${ }^{172}$ The FII and Test Claimants cases cannot be indicative, as the decision of the Court not to grant prospectivity was based to a large extent on the absence of any proof as to the exact damage the decision would cause and the insufficient substantiation of the case by the defendants.

This moderate approach that the Court has traditionally had is also reflected in its most recent, post-crisis, judgments. ${ }^{173}$ Nevertheless, the need for the Court to perceive budgetary difficulties as a separate ground for a prospective ruling on reasons of economic efficiency has been suggested in literature, ${ }^{174}$ on grounds that a potentially severe budgetary impact would affect not only the Member State as such, but also its citizens and its social policies, ${ }^{175}$ and would possibly result in an increased tax rate to cover for the loss, or a 'new tax' or even reduced public services.

In view of the above, it would be reasonable to demand the use of budgetary difficulties as a separate ground for justifying the limitation of

plea of temporal limitation, to ensure that the Court has before it sufficient information to allow it to come to a judgment on the issue. For similar reasons as I enunciated in that case - in which the UK also raised the issue of temporal limitation solely at the oral stage of the procedure, without indicating how it arrived at its estimate of the cost of the case, or giving argument as to the proposed cut-off date for the effects of the judgment - the Court should dismiss the plea.'

170 Test Claimants in the Thin Cap Group Litigation (n 34).

${ }^{171}$ Banca Popolare di Cremona v Agenzia Entrate Ufficio Cremona (n 149)

172 EKW and Wein \& Co (n 140).

173 Case C-184/99 Grzelczyk [2001] ECR I-6193, para 52; Case C-209/03 Bidar [2005] ECR I-2119, para 68; and Case C-2/09 Kalinchev [2010] ECR I-4939 para 52; Case C-387/11 European Commission $v$ Kingdom of Belgium [2012] (nyr); Joined Cases C-338/11 to C-347/11 Santander Asset Management SGIIC and Others [2012] ECR I-0000, para 61, where the Court held that: 'As regards the French Government's reference to the far-reaching budgetary consequences of the Court's present judgment, it is settled case-law that the financial consequences which might ensue for a Member State from a preliminary ruling do not in themselves justify limiting the temporal effects of the ruling'.

${ }^{174}$ Henk Vording and Allard Lubbers, 'The ECJ, Retrospectivity and the Member States' Tax Revenues' (2006) British Tax Review 91, 107.

175 The day AG Stix-Hackl submitted her opinion to the Court on the Meilicke case (n 149) the German government issued a press release stating that the opinion ran counter to all 'Sachverstand', was 'completely incomprehensible and in violation of the fundamental interests of a Member State and its citizens'. 
the temporal effects of the judgment, all the more so in times of economic crises, where the need for budgetary stability, discipline and compliance with the targets is essential not only for one Member State, but also for the future of the Euro zone and the Euro as a whole. Effectively, such a suggestion would not disturb the legal reasoning of the Court, as the outcome of the case would remain unchanged: the Court would reach exactly the same conclusion regardless of the prospectivity claim; it would, however, grant the limitation of temporal effects to Member States capable of proving that a retrospective judgment would seriously undermine their budgetary soundness.

The downside of the straightforward acceptance of the budgetary difficulties argument is primarily that, with a lack of clear estimations, the amount of tax revenues at stake can be easily exaggerated by the Member States concerned. ${ }^{176}$ This peril, in addition to the absence of a de minimis rule, would make this already political and economic choice of the Court even more political, unpredictable and uncertain: what amount would be sufficient and necessary to 'undermine the budgetary' soundness of a Member State, and who would assess it? With a lack of precise quantifications and of a specific test, one could argue that the burden of granting prospectivity would inevitably fall on the good faith of the Member State which would prevent a 'cheating' Member State from benefiting from this tool. ${ }^{177}$ Such a solution would not provide, however, for a more 'robust' legal framework, as good faith is difficult to (dis)prove in such case law that is inconsistent and lacking in legal certainty. Thus, in view of the legal uncertainty, unpredictability and inconsistency of the direct tax case law, as demonstrated under section 4, it is submitted that in many 'unclear' or 'even contradictory' areas, the 'good faith' component of the limitation of the temporal effects of the judgment should be assumed by the Court. Such a development would (re-)shift the burden for the granting of prospectivity back to the financial repercussions of the judgment.

Evidently, the Court would de facto be obliged to make political and policy choices and it is my view that in the crisis context, these choices should be as lenient as possible for the budgets of the Member States. Limiting the judgment's retroactivity on grounds of serious budgetary difficulties, on the assumption of good faith, would, in addition, protect the other taxpayers against arbitrary tax increases which would be necessary to remedy the budgetary deficit caused by CJEU judgments involving huge tax revenue if retroactivity was not limited.

\footnotetext{
176 See also Test Claimants in the Thin Cap Group Litigation (n 34) and Test Claimants in the FII Group Litigation (n 8).

177 See Meilicke (n 149).
} 
The Court has so far only vaguely provided for the groundwork for such a 'justification' of prospectivity to apply. An analysis of the tax cases decided by the Court since the outbreak of the crisis in 2008 shows that there have been only eleven judgments on taxation (direct, indirect, customs and excise duties) whereby the Member States at issue applied for a limitation of the temporal effects of the judgments. ${ }^{178}$ Six of them were related to VAT and excise duties issues. The application for prospectivity was rejected in five of them, but in the Marks and Spencer (II) case, ${ }^{179} \mathrm{de}-$ cided in April 2008, the Court ruled that it was for the national court to decide whether such a limitation would apply. By contrast, in the three direct taxation cases ${ }^{180}$ that revolved around income and property taxation, dividend taxation and withholding taxes, as well as the interpretation of the parent-subsidiary Directive, the Court did not grant the limitation.

The Court cannot be entirely blamed for not granting this limitation despite the financial crisis context. The unexpected scarcity of prospectivity claims by the Member States, the aforementioned dangers of the exaggeration of the amounts at stake, the risk of abusive claims of prospectivity, as well as the last minute advancement of the request (during the hearing) have been identified in the Court's recent case law in taxation. Although the Court seems to be prepared to accept that the limitation of temporal effects can apply also to judgments initiated under the infringement procedure, ${ }^{181}$ it finds the simple quantification of the amounts at stake insufficient, ${ }^{182}$ while it considers of utmost importance the demonstration of a risk of serious economic repercussions if the limitation is not granted.

178 Case C-525/11 Mednis [2012] ECR I-0000; Case C-263/11 Rēdlihs [2012] ECR I-0000; Case C-2/09 Kalinchev [2010] ECR I-4939; Case C-138/07 Cobelfret [2009] ECR 1-731; Joined Cases C-95/07 and C-96/07 Ecotrade [2008]; Case C-309/06 Marks \& Spencer II [2008] ECR I-2283.

${ }^{179}$ In Marks and Spencer II (n 178) para 60: 'It is for the national court itself to draw any conclusions with respect to the past from the infringement of the principle of equal treatment referred to in point 3 of the operative part of this judgment, in accordance with the rules relating to the temporal effects of the national legislation applicable in the main proceedings, in compliance with Community law and, in particular, with the principle of equal treatment and the principle that it must ensure that the remedies which it grants are not contrary to Community law.'

180 Cobelfret (n 178); Santander Asset Management SGIIC and Others (n 173), where the limitation was not granted because the French government, which requested only at the hearing that the temporal effects of the present judgment be limited, failed to put forward any data at the hearing). Similarly in European Commission v Kingdom of Belgium (n 173).

${ }^{181}$ European Commission v Kingdom of Belgium (n 173) para 90: ‘...] Even if judgments delivered under Article 258 TFEU were to have the same effects as those delivered under Article 267 TFEU and considerations of legal certainty might make it necessary, exceptionally, to limit their temporal effects provided that the conditions laid down by the Court's case-law in the context of Article 267 TFEU are met'.

182 ibid para 91. 


\section{Decrease in the number of references for a preliminary ruling?}

A potential redemption possibility for the Member States' budgets would be a decrease in references for preliminary rulings sent to the CJEU. Times of crisis, the need for new implementing measures, as well as the commitment to transpose all the new economic governance legal framework are likely to alter the balanced collaboration and constructive dialogue between the national judge and the CJEU. A very 'active' interpretation by the Court that would strike down national tax systems, such as the one observed in the 'middle' years, could lead to an implicit 'boycotting' of the CJEU by the national referring Courts. ${ }^{183}$ The often enormous budgetary implications of tax judgments and a possibly negative approach of the Court towards national tax systems could deter the national Courts from sending references for preliminary rulings to the CJEU and would lead to the (most convenient) interpretation of EU law by them. ${ }^{184}$ Additionally, given the fundamental issues of sovereignty that tax measures generally deal with, we expect a decrease in the number of references for a preliminary ruling sent by the national courts to the CJEU, with the consequence of the empowering of the national judge over the Community judge.

Such conduct would be further enhanced in view of the considerable importance the acte clair doctrine has acquired as a way whereby the national court can avoid making references to the Court of Justice, ${ }^{185}$ either by adopting a liberal approach to the application of the CILFIT conditions or by adhering to a flexible margin of appreciation made possible under the acte clair doctrine.

General data from the Court of Justice point nevertheless to a steady increase in references for preliminary rulings, as the following table shows: ${ }^{186}$

\footnotetext{
${ }^{183}$ Michael Graetz and Alvin C Warren Jr, 'Income Tax Discrimination and the Political and Economic Integration of Europe' (2006) 115 Yale Law Journal 1186.

${ }^{184}$ Case 283/81 CILFIT and Others [1982] ECR 3415. The Court established in the CILFIT case the acte clair doctrine according to which a court or tribunal against whose decisions there is no judicial remedy under national law is required, where a question of Community law is raised before it, to comply with its obligation to bring the matter before the Court of Justice, unless it has established that the question raised is irrelevant or that the Community provision in question has already been interpreted by the Court or that the correct application of Community law is so obvious as to leave no scope for any reasonable doubt (para 21). See also Case C-495/03 Intennodal Transports [2005] ECR I-0000, para 33.

185 Niels Fenger and Morten P Broberg, 'Finding Light in the Darkness: On the Actual Application of the Acte Clair Doctrine (2011) 30 Yearbook of European Law 180.

186 Data from the CJEU, Annual Report 2012, Luxembourg 2013

http: / / curia.europa.eu / jcms / upload/docs / application / pdf/ 2013 04/192685_2012_6020_cdj_ra_2012_en_proof_01.pdf> accessed 11 December 2013. The insignificant decrease observed in 2012 is proportionate to the overall decrease of new cases brought before the Court.
} 


\begin{tabular}{|l|c|c|c|c|c|}
\hline & 2008 & 2009 & 2010 & 2011 & 2012 \\
\hline $\begin{array}{l}\text { New cases under the procedure of } \\
\text { references for preliminary rulings } \\
\text { (Art 267 TFEU) }\end{array}$ & 288 & 302 & 385 & 423 & 404 \\
\hline $\begin{array}{l}\text { TOTAL number of new cases } \\
\text { (regardless of the procedure) }\end{array}$ & 593 & 562 & 631 & 688 & 632 \\
\hline
\end{tabular}

While this also holds true for the direct taxation cases, most of which reach the Court under the $267 \mathrm{TFEU}$ procedure, it is interesting to examine whether this also applies to a) Member States such as Ireland and Cyprus which place particular weight on their tax systems to attract investment and establishment; b) Member States which maintain very 'fragile' budgets because of the crisis.

With regard to the first case, Ireland and Cyprus constitute (together with Estonia) the countries with the lowest corporate tax rates in the EU. Not only do they thus represent the two leading examples in tax competition but they also form two prominent examples of a lack of balanced judicial cooperation in taxation. Ireland and Cyprus have thus never so far sent a reference for a preliminary ruling to the Court, although they have 'suffered' a lot from infringement proceedings initiated by the Commission. The example of these two states famous for their taxpayer-friendly tax systems tells of the reluctance of Member States that use taxation as a main 'bait' to attract investment and establishment to resort to the CJEU to ensure that their tax systems are compatible with EU law.

With reference to the second category, I consider the Member States most affected by the crisis the PIGS countries or, put differently, the Member States that resorted to the financial assistance mechanisms so as not to default. ${ }^{187}$ Although not all these Member States requested financial assistance at the same time, the time framework of the last 5 years seems accurate with respect to the outbreak of the economic crisis. Judging from the high number of 'lost' cases for the Member States in the recent past, it can be expected that the number of references for preliminary rulings in tax matters from the financially distressed states will decrease.

In order to examine whether the crisis and the 'fragile' budgets have deterred the Member States most affected by the crisis to send references for preliminary rulings to the CJEU, we compare the number of references sent by the PIGS countries (with regard to taxation, both direct and indirect) in the last 5 years, as well as in the period between October

\footnotetext{
187 Cyprus is intentionally left out because of its very recent inclusion in the list of the 'financially assisted' Member States.
} 
2003 and October 2008 (the 5 years previous to the crisis). The findings of this comparison demonstrate that we cannot observe any major changes in the number of references sent in the last 5 years and in the 5 years previous to them. Thus, estimations show that in the last 5 years, Portugal has sent to the CJEU 7 references for preliminary rulings, ${ }^{188}$ Spain has sent 8 references for preliminary rulings with regard to both direct and indirect taxation, ${ }^{189}$ whereas Greece has not sent any. With the exception of Greece, which had sent 3 references for preliminary rulings (all on VAT issues) in the period from 2003 to 2008, data from Portugal and Spain for that period demonstrate that the former had sent 5 references for preliminary rulings ( 3 on VAT, one on indirect taxation and one on corporate taxation), whereas Spain had sent 2, both on VAT matters. While the numbers cannot provide any conclusive evidence of Greece's potential change of stance towards judicial cooperation and the need to safeguard national budgets, the overall trend drawn from the examples of Portugal and Spain seems to safely allow the conclusion that there has been a sharp decrease in the number of preliminary rulings for the $\mathrm{P}(\mathrm{I})$ (G)S countries.

Overall, it cannot be concluded that because of the financial crisis the balanced collaboration and constructive dialogue between the national judge and the CJEU has altered. National courts continue sending references for preliminary rulings even in an area as 'dangerous' for the national budgets as direct taxation. A possible contribution to this has been the positive shift of the Court towards a more respectful approach to the national tax systems, as well as the persistent complexity of the area that necessitates such a stance by the Court. In contrast, countries, notably Ireland and Cyprus, whose economy is heavily based on the tax incentives they provide, have always refrained from putting in jeopardy their tax systems. On these grounds, the crisis clearly has not had any implications for these Member States.

\footnotetext{
188 Case C-282/12 Itelcar-Automóveis de Aluguer Lda v Fazenda Pública [2013] (nyr) (on corporate taxation); Case C-38/11 Amorim Energia [2012] OJ C130; Case C-496/11 Portugal Telecom [2012] ECR I-0000 (on VAT); Case C-25/11 Varzim Sol [2012] ECR I-0000 (on VAT); Case C-126/10 Foggia - SGPS [2011] ECR I-0000 (on mergers' taxation); C-106/10 Lidl \& Companhia v Fazenda Pública [2011] ECR I-0000 (on VAT).

189 Case C-125/12 Promociones y Construcciones BJ 200 SL [2013] (nyr) (on VAT); Case C-377/11 International Bingo Technology SA [2012] ECR I-0000 (on VAT); Case C-285/10 Campsa Estaciones de Servicio [2011] ECR I-0000 (on VAT); Case C-157/10 Banco Bilbao Vizcaya Argentaria [2011] ECR I-0000 (on corporate taxation); Case C-118/08 Transportes Urbanos y Servicios Generales [2010] ECR I-635 (on VAT); Case C-487/09 Inmogolf SA [2010] (on indirect taxes); and Joined Cases C-428/06 to C-434/06 UGT-Rioja and Others [2008] ECR I-6747 (on fiscal aid); Case C-151/08 Renta [2008] OJ C150 (on VAT).
} 


\section{Conclusion}

The financial/sovereign debt crisis does not seem to have affected either the Court's legal reasoning or the outcomes of the judgments. The Court, along the pattern established in 2005, follows a friendlier approach towards the Member States' budgets, in particular in comparison to the early years; its case law, however, remains fragmented and its reasoning susceptible to instrumental use. In view of this, the fact that in most cases Member States' national tax measures are still found incompatible with the four freedoms demonstrates that the Court is very little affected by economic considerations, even in the light of the crisis.

With reference to the limitation of the temporal effects of the judgment, we reach the same conclusion if we consider the 'crisis' case law. While in earlier cases, where the amounts at stake were particularly large, the CJEU seemed to take account of the tremendous budgetary implications for the Member States and grant the prospectivity of the ruling, recent cases have not revealed such a pressing need. This happens because, quite surprisingly, we do not observe an 'explosion' of applications for the limitation of temporal effects, and in cases where the Member States have asked for prospectivity, they have not 'played' the limitation of temporal effects card correctly. It is advocated that, particularly in such times of crisis, and in view of the inconsistent, unpredictable and unclear case law, the Court should be more lenient in the granting of prospectivity in cases of serious budgetary implications, while the Member States should demonstrate the serious economic repercussions and substantiate their claims using as proof accurate estimations of the financial impact of the judgment.

Finally, the Member States themselves appear still to trust the judgments of the CJEU despite the aforementioned malaises. No decrease in the number of references for preliminary rulings in the area of taxation can be observed, implying that the Member States are not attempting to induce a shift of the Court to a more 'lenient' approach towards their budgets. As opposed to the 2005 critical juncture, the Member States do not want to coerce the Court with political or 'institutional' pressure to respect more their national tax systems.

Since this paper has departed from the claim that the CJEU does consider the political and economic costs of its decisions, the opposite conclusion appears rather surprising. Why has not the Court taken a more active stance, similar to the 'constitutional-making' principles in previous crises to 'alleviate' the Member States faced with such a crisis? One potential reason, as this paper has already implied, is that the Court has not been particularly incentivised by the Member States to 
do so. ${ }^{190}$ Another possible justification for this lack of a 'jurisprudential shift' could be that the Court has not - so far - been confronted with any 'crisis-related' tax measures. In view of the case law amenable to instrumental use, the Court could, arguably, have reacted differently if it had had to address a 'crisis related' or 'a crisis induced' specific tax measure. In such a case, the CJEU could show more latitude towards the Member States' budgets so as to endorse the specific intentions of the legislator. Finally, the 'integrative function' inherent to the Court as reflected in both the specific pre-2005 direct taxation case law, as well as the Court's case law in the 1970s, could allow the more general conclusion that the Court might not be prepared to repudiate this 'integrationist' role it has been granted in past decades. Limiting the scope of the application of EU law, even when this seems politically and economically acceptable, seems much harder to ask for from the 'integration catalyst'. One should not forget, however, that both economic and political integration is eventually achieved through the Member States. Taking into account the Member States' interests, in particular in such times of unprecedented crisis, is therefore of vital importance in holding the 'EU construct' together.

\footnotetext{
190 This finding is particularly advocated by the steady increase in the number of references for preliminary rulings (even in tax matters), as well as the applications for a limitation of the temporal effects of the judgment, which have been 'underplayed' by the Member States.
} 